\title{
Komunikační písemnosti okresního politického úřadu v Boskovicích a jejich proměny na přelomu 19. a 20. století
}

Jaromír Florian / 361413@mail.muni.cz

Ústav pomocných věd historických a archivnictví, Filozofická fakulta, Masarykova univerzita

\begin{abstract}
In this study, we attempt to classify, describe and name individual types of documents used by the district council in Boskovice in written contact with authorities, organizations and private persons in the years 1870-1928. The structure is based on a combination of rank and formality. We then scrutinize the documents across the entire page, and we focus on papers and personal papers used exclusively by the district governor as the head of the office. We also deal with what are formally the simplest communication documents - indorsements. In a separate chapter we discuss the modernization of communication papers at the end of $19^{\text {th }}$ and beginning of the $20^{\text {th }}$ century. The text is supplemented by examples of selected documents in a separate pictorial appendix.
\end{abstract}

\section{Keywords}

diplomatics, official communication papers, $19^{\text {th }}$ and $20^{\text {th }}$ century, district council 


\section{Základní literatura a prameny, metoda}

Komunikačním písemnostem vydávaným okresními politickými úřady z let 1850-1945 nebyla dosud věnována - až na několik výjimek - zvláštní pozornost. ${ }^{1}$ Zatím chybí komplexní zpracování daného tématu, jež by postihovalo veškeré druhy komunikačních písemností a jejich vývoj v celém, téměř stoletém období existence okresních úřadů a zasadilo jej do kontextu vývoje této skupiny písemností v prostředí politické správy. Předkládaná studie představuje první krok k souhrnnému zpracování této látky.

Navzdory absenci širšího pohledu a detailnějšího zpracování byly několika průkopnickými diplomatickými studiemi položeny základy bádání v této oblasti, o něž se může badatel opřít, než přistoupí k vlastnímu výzkumu založeném na analýze dochovaných archivních pramenů.

Na prvním místě zasluhuje zmínku diplomová práce Marty Šopfové z roku 1959. ${ }^{2}$ V této průkopnické studii předkládá autorka typologii a popis komunikačních písemností vydávaných okresními úřady, především v počátečním období jejich existence, tedy v letech 1850-1868. ${ }^{3}$ Výklad se opírá především o ustanovení úřední instrukce č. $52 / 1855$ ř. z. pro okresní úřady a soudobé příručky určené úředníkům státní správy. Nejpodrobněji jsou popsány písemnosti určené nadřízeným př́iemcům, charakteristiky dalších jsou stručnější. Podrobný a systematický rozbor vnějších a vnitřních znaků chybí, setkáváme se spíše s definicemi dle dobových pojednání nebo právních předpisů a norem. Navzdory poctivé snaze o komplexní uchopení dané problematiky je výklad zatížen řadou nepřesností a chyb, což patrně pramení z nedostatečné analýzy dochovaných čistopisů komunikačních písemností.

Značnou hodnotu má rozsáhlá studie Evy Šmilauerové o správním vývoji a diplomatice písemností okresních národních výborů. ${ }^{4}$ Okresní národní výbory převzaly roku 1945 komunikační písemností svých předchůdců - zrušených okresních úřadů. Bohužel některé typy komunikačních písemností - hlavně nejběžnější úřední korespondence s úřady na roveň postavenými a podřízenými - zůstávají mimo autorčin zájem. Tato skutečnost pramení, a dokládá to i vyjádření Šmilauerové, ${ }^{5}$ ze značné formální a stylizační nevyhraněnosti oněch písemností, jak o tom pojednáváme níže na jiném místě.

Hutností a hloubkou zpracování vyniká drobná studie Antonína Macáka o písemnostech krajské vlády v Plzni v letech 1850-1855. . Autor v ní podává zevrubný popis vnějších a vnitřních znaků komunikačních písemností a zároveň přináší i jejich typologii. Při

1 Jelikož se pojmenování prvoinstančních úřadů politické správy v průběhu jejich existence měnilo (okresní hejtmanství, okresní úřad, okresní správa politická), užíváme v této studii obecných označení okresni uírad a okresni politický úrad.

2 Šopfová, Marta: Písemnosti okresnich hejtmanství na Moravě 1850-1918. Diplomová práce. Brno 1959.

3 Srov. tamtéž, s. 4.

4 Šmilauerová, Eva: Správni vývoj a diplomatika písemností okresních národních výborů v letech 1945-1960. SAP 32, 1982, s. 43-169.

5 Srov. tamtéž, s. 157.

6 Macák, Antonín: Písemnosti krajské vlády v Plzni 1850-1855. K diplomatice písemností nižších orgánů státní správy. Západočeský historický sborník 3, 1997, s. 5-28. 
pojmenování písemností vycházel Macák podobně jako Šmilauerová z vydaných právních předpisů nebo dobových příruček pro úředníky. Posuzujeme-li relevantnost této studie pro naše téma, musíme si uvědomit, že předchůdci krajských vlád krajské úřady byly až do konce roku 1849 nejnižší instancí plně postátněné politické správy, ${ }^{7}$ přičemž organizace, jakož i způsob úřadování nově zřízených okresních úřadů (hejtmanství) nutně navazovaly na starší vzory. ${ }^{8}$

Jádro našeho výzkumu spočívalo v analýze a sledování proměn vnějších a vnitřních znaků čistopisů komunikačních písemností okresního politického úřadu v Boskovicích dochovaných v prezidiální a všeobecné registratuře. ${ }^{9} \mathrm{Z}$ časového hlediska náš výzkum pokrývá období let 1870-1928.

Při shromaždování čistopisů jsme mohli využít příznivé okolnosti, že se ve spisovém materiálu poměrně často vyskytují i čistopisy části expedovaných komunikačních písemností. Ve spisech narazíme nejčastěji na nařízení určená podřízeným úřadům, a to díky jejich zvyku psát odpověd' v určitých případech přímo na rub došlého nařízení. Někdy byl čistopis vrácen úřadu spolu s podávanou zprávou. V poněkud menší míře je dochovaná korespondence s úřady nebo jinými př́ijemci postavenými na roveň. Po roce 1900 je navíc dochováno minimum čistopisů vydaných boskovickým okresním úřadem, a proto jsme si dovolili využít pro účely analýzy i písemnosti došlé, byl-li jejich původcem některý okresní úřad, popřípadě jeho šéf. Čistopisy zpráv nalézáme ve spisech vzácněji, ale při podrobném procházení vytipovaných kartonů není těžké shromáždit reprezentativní množství jejich exemplářu. Abychom získali větší počet čistopisů zpráv a také představu o podobě komunikačních písemností v 50.-60. letech 19. století, tj. v období, pro něž není dochován spisový materiál boskovického úřadu, ${ }^{10}$ podnikli jsme šetření v registratuře prezidia moravského místodržitelství. ${ }^{11}$

\section{Hlediska pro určování typů komunikačních písemností}

Při určování jednotlivých typů písemností jsou rozhodující následující kritéria:

1) hodnostní vztah mezi původcem (okresním úřadem) a př́ijemcem

a) podřízenost - například ve vztahu k moravskému místodržitelství (od roku 1919 zemské správě politické) nebo zemskému finančnímu ředitelství (do roku $1919)^{12}$

7 Kolektiv autorů: Historický mistopis Moravy a Slezska v letech 1848-1960. Sv. I. Územněsprávní vývoj státních a společenských institucí a organizací na Moravě a ve Slezsku v letech 1848-1960. Ostrava 1966, s. 18.

8 Srov. Šopfová, M.: Písemnosti, s. 108.

9 Státní okresní archiv Blansko (dále SOkA Blansko), Okresní úřad Boskovice 1850-1945 (1954) (dále OÚ Boskovice).

10 Pokud se nějaké spisy z tohoto období dochovaly, pak jedině v rámci prior připojených k mladším spisům.

11 Moravský zemský archiv v Brně (dále MZA), B 13 Moravské místodržitelství - prezidium (dále B 13), sg. 2/3, kart. 704, 730, 736, 737, 742, 743, 748.

12 Pouze do ustanovení berních správ z dosavadních berních referátů okresních hejtmanství roku 1919. Srov. Kolektiv autorů: Historický místopis, s. 109. 
b) rovnost neboli koordinovanost - napřríklad ve vztahu k ostatním okresním politickým úřadům, okresním soudům nebo berní správě (od roku 1919) na území domácího politického okresu

c) nadřízenost

- přímá (služební) nadřízenost - například ve vztahu k obecním a městským radám, okresnímu četnickému velitelství a jednotlivým četnickým stanicím, do roku 1919 též ve vztahu k berním úřadům domácího politického okresu

- kompetenční nadřízenost, jež vyplývá z pravomoci okresního úřadu př́ímo jednat za účelem odstranění určitého stavu, který odporuje právním předpisům, ${ }^{13}$ a rozhodovat o žádostech jemu předložených

2) formální úprava písemnosti

Jedná se o složení a uspořádání formuláře písemnosti, u něhož lze rozlišit tyto hlavní části:

a) označení vydavatele

b) oslovení adresáta

c) datační formule

d) předpodpisová formule

- její nejčastější podoby jsou:

- Der k. k. Bezirkshauptmann (C. k. okresni hejtman $)^{14}$

- Der k. k. Statthaltereirat (C. k. mistodržitelský rada) - byl-li okresní hejtman místodržitelským radou ${ }^{15}$

- Der k. k. Amtsleiter (C. k. správce úřadu) - vedl-li okresní hejtmanství úředník nižší hodnosti, než odpovídá titulu okresni hejtman - například okresní komisař

- Für den k. k. Bezirkshauptmann / Statthaltereirat (Za c. k. okresniho hejtmana / mistodržitelského radu) - podepisuje-li písemnost místo okresního hejtmana jeho zástupce, jímž byl zpravidla hodnostně nejvýše stojící referent po šéfovi úřadu

- Der k. k. Bezirkshauptmann / Statthaltereirat i. V. (in Verhinderung, př́ipadně in Vertretung), česky C. k. okresni hejtman / mistodržitelský rada $v$ z. (v zastoupení)

- v době, kdy není v písemnostech udáván název úřadu, umožňuje tato předpodpisová formule určení vydavatele ${ }^{16}$

13 Šmilauerová, E.: Spráuni vývoj a diplomatika, s. 153.

14 Okresni hejtman byl také úřední titul náležící konceptnímu úředníkovi VII. hodnostní tř́ídy.

15 Titul mistodržitelský rada náležel konceptnímu úředníkovi VI. hodnostní tř́ídy.

16 Po vzniku Československa mizí z úředních titulů př́ílastek císařsko-královský. Vládním nařízením č. 244/1923 Sb. z. a n. dochází k dílčí reformě úředních titulů za účelem odstranění nežádoucích př́vlastků mistodržitelský a dvorni. Titul okresni hejtman zůstává ponechán, ale někdejšího místodržitelského radu nahrazuje rada politické správy. K další změně pak dochází na základě vládního nařízení č. 103/1927 Sb. z. a n., jímž se místo dosavadního titulu okresní hejtman zavádí rada politické správy. Titul rada politické správy ve smyslu vládního nařízení z roku 1923 je nahrazen titulem vrchni rada politické správy (odpovídá někdejší- 
e) vlastnoruční podpis nebo otisk podpisového razítka šéfa úřadu či jeho zástupce

f) vnitřní adresa

g) stručné shrnutí obsahu písemnosti (rubrum)

h) vnější adresa

3) forma vyhotovení čistopisu

a) per extensum - na samostatném listě nebo dvojlistě, text psán po celé šiřce stránky

b) in dorso - na rubu či poslední straně došlé písemnosti nebo samostatného listu, text psán po pravé, nebo levé polovině stránky

4) znění stylizačního jádra písemnosti a kurtoazní prvky

Písemnosti určené nadřízeným, na roveň postaveným a výjimečně též níže postaveným (nikoliv však podřízeným) př́ijemcům obsahují stylizační jádro tvořené pomocí slovesa beehren nebo opisného sich die Ehre geben, možná je i konstrukce s neosobním zájmenem man. Toto zdvořilostně laděné znění stylizačního jádra doplňují kurtoazní slůvka jako např́ílad ergebenst, ehrfurchtsvoll, dienstfreundlichst nebo höflichst $\mathrm{v}$ závislosti na hodnostním vztahu úřadu $\mathrm{k}$ adresátovi. Písemnost pak může začínat například „Ich beehre mich ergebenst zu berichten ... “ nebo „Man gibt sich die Ehre höflichst mizutheilen ... “. Kromě toho nacházíme v písemnostech okresního úřadu kurtoazní oslovení hochlöblich nebo hoch pro nadřízené a löblich pro koordinované úřady. Výše uvedené charakteristiky platí jenom do konce 19. století.

5) gramatická stylizace

a) subjektivní

- v 1. osobě singuláru (jménem šéfa úřadu), např. „Vaši žádosti ... se mi nevidí ... vyhovèti. “

- v 1. osobě plurálu (zcela výjimečně), napřs. „Žádáme o laskavé sdèleni ... “

b) objektivní, tj. ve 3 . osobě

- jménem úřadu, např. „Die k. k. Bezirkshauptmannschaft in Boskowitz findet Ihnen die Concession ... hiemit zu verleihen ... “, „C. k. okresni hejtmanstvi v Boskovicích udèluje Vám povoleni ..."

- pomocí pasivních konstrukcí, např. „Herr Gemeindevorsteher wird aufgefordert ..." ", „Pan starosta se vybizi ..."

c) v imperativu pasivním (budiž oznámeno) nebo aktivním (oznamte) - pouze v česky psaných písemnostech

mu místodržitelskému radovi). V závislosti na těchto proměnách se po roce 1918 vyvíjelo i konkrétní znění předpodpisové formule. 


\section{Jazyk písemností}

Než přejdeme k výkladu o vlastních písemnostech, zmíníme se alespoň ve stručnosti i o jejich jazykové stránce.

Jazykem písemností adresovaných nadřízeným a na roveň postaveným příjemcům byla až do vzniku samostatného československého státu výhradně němčina. Výjimku tvoří krátké období let 1897-1899, kdy platila Badeniho, ${ }^{17}$ následně pak Gautschova jazyková nařízení, ${ }^{18}$ dle nichž se na Moravě vnější i vnitřní úřední jazyk u politických úřadů řídil jazykem prvního podání v dané záležitosti. Čeština se tak stává jazykem téměř veškeré úřední korespondence, ale například též jazykem zápisů v podacích protokolech nebo i různých interních poznámek ve spisech. ${ }^{19}$

U písemností vydávaných podřízeným příjemcům platila dle tzv. Stremayrových jazykových nařízení z roku 1880 zásada, že na české podání následuje česká odpověd'. ${ }^{20}$ Tuto praxi nicméně můžeme - byt patrně ne zcela důslednou - sledovat již dříve, a rok 1880 tak patrně přinesl pouze kodifikaci existujícího stavu.

Po vzniku Československa nahrazuje němčinu ve vnějším i vnitřním úřadování prakticky okamžitě čeština. Z názvu úřadu a úředních titulů uváděných v písemnostech zároveň mizí př́ílastek císařsko-králouský.

\section{Písemnosti pro nadřizené přijemce}

\subsection{Zprávy}

Pro komunikaci okresních úřadi̊ s nadřízenými úřady nebo s jejich představenými předepisuje úřední instrukce č. 52/1855 ř. z. zprávy (Berichte).$^{21} \mathrm{Na}$ rozdíl od ostatních písemností zmiňovaných v instrukci je zprávám věnována podstatně větší pozornost. ${ }^{22}$ Zprávy se poměrně dosti liší od relací užívaných nejvyšším zeměpanským úřadem na Moravě v letech $1748-1782 .^{23}$

17 Ministerská nařízení ze dne 22. dubna 1897. Na Moravě byla publikována 25. dubna jako zákony č. 29 a $30 / 1897$ z. z.

18 Ministerské nařízení ze dne 24. února 1898. Na Moravě bylo publikováno 5. března jako zákon č. 19/1898 z. z. Platnost Gautschových jazykových nařízení rušila tzv. Claryho jazyková nařízení vydaná 14. října 1899. Na Moravě byla publikována dne 17. ř́ijna jako zákon č. 77/1899 z. z.

$19 \mathrm{~S}$ četnictvem však okresní hejtmanství i v této době komunikovalo výhradně v němčině.

20 Ministerské nařízení ze dne 19. dubna 1880. Na Moravě bylo publikováno 28. dubna pod č. $17 / 1880$ z. z.

21 Verordnung der Minister des Innern und der Justiz vom 17. März 1855. Reichs-Gesetz-Blatt für das Kaiserthum Oesterreich, Jahrgang 1855, http:/ /alex.onb.ac.at/ cgi-content/alex?apm=0\&aid=rgb\&datum=18550004\&seite $=00000337 \&$ size $=45$, citováno 23. 4. 2018.

22 Srov. § 91 a 100 úřední instrukce.

23 Srov. Sviták, Zbyněk: Z počátků moderni byrokracie. Nejvy̌̌ši zeměpanský úřad na Moravě v letech 1748-1782. Brno 2011, s. 422-432. 
Úřad jejich prostřednictvím podává hlášení, předkládá vypracovaný jednací spis nebo odvolání (i s př́ípadným návrhem na schválení či zamítnutí) k rozhodnutí nebo žádá o radu, jak postupovat v nějaké konkrétní záležitosti. Zprávy mohou být stylizovány jak objektivně za užití pasivní konstrukce, tak i subjektivně v 1. osobě singuláru (jménem šéfa úřadu). Jejich adresátem je bud' nadřízený úřad, případně presidium onoho úřadu, nebo jeho představený. Podřízenost okresního úřadu se zračí v užívání kurtoazních slov ergebenst, erfurchtsvoll apod. (např. „... wird ergebenst berichtet ... “).

Od 70. let 19. století bývají zprávy boskovického úřadu psány výhradně per extensum na dvojlistu (archu), přičemž jeden list (půlarch) má tehdy standardní rozměry $21 x 34$ cm. Původně se pravděpodobně nechávala levá polovina stránky prázdná. ${ }^{24} \mathrm{~V}$ pravém horním rohu na první straně je nadepsáno číslo jednací písemnosti. ${ }^{25}$ Zprávy začínají oslovením adresáta, přičemž je nadřízený úřad titulován jako hochlöblich nebo hoch (Hohe k. k. Statthalterei!). Přívlastek hoch náleží též místodržitelským výnosům. Pokud zpráva reaguje na nějaký místodržitelský výnos, je v úvodu citován (např. „In Erledigung des hohen Erlasses vom ... Z Z [ahl] ... "). Po této úvodní části se přechází přímo k jádru věci. Zpráva je zakončena datační (místo a datum) a předpodpisovou formulí rozdělenými do dvou řádků, ${ }^{26}$ po nichž následuje hejtmanův vlastnoruční podpis. Vlastnoruční podpis šéfa úřadu, popř́ípadě jeho zástupce, zůstává ověřovacím prostředkem u zpráv i tehdy, když se u běžných komunikačních písemností prosazuje užívání podpisového razítka.

Na poslední straně dvojlistu bylo po pravé polovině psáno rubrum obsahující oslovení adresáta, označení původce, citaci čísla jednacího výnosu, na nějž se odpovídá, a krátké shrnutí obsahu předkládané zprávy, případně ještě vyznačení počtu příloh. Rubrum je formulováno objektivně (např. „Hohe $k$. $k$. Statthalterei. Der k. k. Bezirkshauptmann in Boskowitz überreicht...").

Je-li adresátem místodržitel, objevuje se v čele písemnosti oslovení ve tvaru Euer Excellenz doplněné vykřičníkem. Část rubra nahrazující vlastně vnější adresu má pak formu dativní (např. „Seiner Excellenz dem Hochgeborenen Herrn Adolf Freiherr von Poche k. k. Statthalter in Brünn“), nebo akuzativní (např. „An Seine Excellenz den Hochgeborenen Herrn ... "). U tohoto typu zpráv, pokud jsou subjektivně stylizovány, se odesílatel může obracet na adresáta i v textu, a to formou nepřímého oslovování (např. „Ich erlaube mir Euer Excellenz ergebenst anzuzeigen, daß ... “), méně často je analogickým způsobem oslovován i nadřízený úřad či jeho prezidium.

Třebaže je subjektivní stylizace do jisté míry typická pro prezidiální agendu, kde okresní hejtman komunikuje s nadřízeným úřadem či jeho představeným, zkoumáme-li zprávy v kontextu jejich vzniku a zpracování příjemcem, zjištujeme, že volba gramatické

24 Např. MZA, B 13, sg. 2/3, kart. 730, fol. 641, 644; čistopis zprávy okresního představeného v Boskovicích z 26. listopadu 1863. Podle $§ 100$ úřední instrukce č. 52/1855 ř. z. má být ponechána prázdná levá čtvrtina stránky.

25 Podle $\$ 98$ úřední instrukce č. 52/1855 ř. z. mělo být číslo jednací uváděno v čistopisech vždy (tedy nejen u zpráv) vlevo nahoře.

26 U zpráv většiny okresních úřadů z 50.-70. let 19. století odděluje úřední titul od vlastnoručního podpisu okresního hejtmana ještě tzv. čára z uctivosti (Devotionsstrich) jako projev kurtoazie. Ve zprávách okresního hejtmanství v Boskovicích se nevyskytuje. K tomu viz Macák, A.: Písemnosti krajské vlády, s. 14. 
stylizace a adresáta (úřad nebo jeho představený) je v podstatě formální záležitostí. Subjektivní i objektivní stylizace nacházejí uplatnění jak v prezidiální, tak i všeobecné agendě. Tato obojetnost patrně vyplývá z monokratického charakteru okresních politických úřadů a projevuje se také u dalších komunikačních písemností.

\subsection{Osobní zprávy}

Prostřednictvím této písemnosti, jež bývá důsledně stylizována v 1 . osobě singuláru, se hejtman obrací (alespoň formálně) př́ímo na místodržitele, jenž je v textu nepř́imo oslovován. Po obsahově-právní stránce nemusí být mezi nimi a výše popsanými zprávami podstatnější rozdíl, přeci jen však mají osobnější charakter, což nachází výraz ve skladbě a uspořádání jejich formuláře.

V pravém horním rohu na první straně písemnosti je nadepsáno číslo jednací. Do čela písemnosti je pravidelně umístěno oslovení adresáta (Euer Excellenz!). Na kontext navazuje kurtoazní formule přibližně tohoto znění: „Genehmigen Euer Excellenz den Ausdruck der vorzüglichsten Hochachtung, mit der sich zeichnet“.27 Po kurtoazní formuli následuje na samostatném řádku počátek předpodpisové kurtoazie v podobě druhého oslovení (Euer Excellenz), pod nímž je při levém okraji stránky umístěna datační formule. Přibližně na úrovni datační formule pokračuje v pravé polovině strany předpodpisová kurtoazie (ergebenster, ergebenster Diener, gehorsamster Diener), pod níž je umístěn vlastnoruční podpis hejtmana, doplněný (taktéž vlastnoručně) jeho úředním titulem, který může chybět. Osobní zprávy bývají opatřeny rubrem.

\section{Písemnosti pro př́jemce na roveň postavené}

\subsection{Písemnosti předepsané úřední instrukcí č. 52/1855 ř. z.}

Dostáváme se nyní k písemnostem užívaným okresními úřady ve vzájemném písemném styku a při korespondenci s koordinovanými úřady. Úřední instrukce č. 52/1855 ř. z. znala nóty (Noten) a listy (Schreiben). O nótách se uvádí, že slouží pro korespondenci s koordinovanými, tj. na roveň postavenými úřady, kdežto listy vyhotovované ve formě dopisu (in Briefform) mají být užívány v písemném styku s přednosty koordinovaných úřadů nebo veřejnými orgány (öffentliche Organe), které nejsou okresním úřadům služebně podřízeny. Právní předpis blí̌ze nepopisuje oba typy písemností, snad i proto, že byly v té době běžně užívány.

Jako první popisuje nóty v moravském prostředí Zbyněk Sviták. Nejvyšší zeměpanský úřad na Moravě je užíval v písemném styku s vrchním vojenským velitelstvím v zemi. ${ }^{28}$

27 Tato kurtoazní formule se občas vyskytuje i v subjektivně stylizovaných zprávách adresovaných místodržiteli, které se pak blíží formě popsané níže jako list. Přítomnost kurtoazní formule je přitom tím jediným, čím se písemnost liší od klasických zpráv. Např. MZA, B 13, sg. 2/3, kart. 730, fol. 411, 412; zpráva okresního představeného v Brně z 22. ledna 1865. 
V 2. polovině 19. století byly nóty (alespoň v oblasti politické správy) standardním nástrojem komunikace na roveň postavených úřadů.

Za současného stavu poznání nejsme schopni zcela bezpečně určit obsah termínu list (Schreiben). Na základě dosavadních zkušeností získaných při sběru čistopisů komunikačních písemností různých původců nicméně předpokládáme, že pod ním současníci rozuměli písemnosti nesoucí v čele (na rozdíl od nót a výnosů) oslovení adresáta (případně snad i vnitřní adresu) užívané v písemném styku s výše postavenými (nikoliv nadřízenými), koordinovanými nebo níže postavenými (nikoliv podřízenými) příjemci, jež mohly, ale nemusely být opatřeny vnější adresou, jejíž řádky směřují kolmo na text písemnosti; pozorujeme u nich tedy některé charakteristické znaky misiv užívaných v letech 1748-1782 nejvyšším zeměpanským úřadem na Moravě. ${ }^{29}$ Zda je užito objektivní, nebo subjektivní stylizace, záleží na okolnostech. Poměr těchto listů k misivám 18. století bude nutné objasnit. Předpokládáme, že užití písemností tohoto typu je projevem kurtoazie tam, kde mezi původcem a př́jemcem neexistuje vztah přímé nadřízenosti nebo podřízenosti, eventuálně v př́ípadě hodnostní rovnosti. Mezi písemnostmi expedovanými boskovickým úřadem se nám je zatím nepodařilo zachytit.

Jako listy (Schreiben) bývají označovány též písemnosti poněkud odlišné od výše popsaného typu. Pozorujeme u nich rozvinutější kurtoazní složku, jsou stylizované v 1. osobě singuláru a postrádají vnější adresu. Touto formou spolu komunikují šéfové úřadů bez ohledu na jejich hodnostní postavení v rámci systému státní správy. ${ }^{30}$ Pokud jde o vzájemnou korespondenci šéfů prvoinstančních (nejen politických) úřadů, dodržují tuto formu jen některé písemnosti, a to ještě ne zcela důsledně (podrobněji viz níže).

Ještě rozvinutější kurtoazní složku včetně některých rozdílů v uspořádání formuláře nalezneme u listů téměř osobního charakteru. ${ }^{31}$ Tyto osobní listy se v korespondenci mezi šéfy úřadi̊ vyskytují vzácněji než forma předešlá. ${ }^{32}$

\subsection{Nóty}

Nóty mohou být stylizovány subjektivně v 1. osobě singuláru nebo objektivně za užití pasiva. Subjektivní stylizace je velmi častá. Některé, obzvláště objektivně stylizované nóty se obracejí na úřad jako celek (např. „... wird der löblichen $k . k$. Bezirkshauptmannschaft mitgeteilt ... "), časem toto zbytečné jmenování adresáta v kontextu odpadá. I v korespondenci koordinovaných úřadů nacházejí uplatnění kurtoazní slůvka, a sice výrazy höflichst

29 Srov. tamtéž, s. 436-444, kde autor popisuje tzv. rekvizitoriální misivy.

30 Tuto formu listu jsme zaznamenali ve vzájemné korespondenci ministra vnitra (státního ministra) s moravským místodržitelem nebo mezi místodržiteli. Např. MZA, B 13, sg. 2/3, kart. 743, fol. 275, 276; list ministra vnitra moravskému místodržiteli z 15. května 1876; tamtéž, kart. 730, fol. 170, 172; list místodržitele ve Štýrském Hradci moravskému místodržiteli z 26. srpna 1865.

31 Jedná se o písemnosti velmi podobné osobním relacím, jejichž prostřednictvím komunikoval prezident nejvyššího zeměpanského úřadu na Moravě v letech 1748-1782 s představenými dvorských úřadů. Srov. Sviták, Z.: Z počátki̊ moderni byrokracie, s. 432-435.

32 Např. SOkA Blansko, OÚ Boskovice, kart. 4, fol. 578, 579; osobní list vídeňského starosty okresnímu hejtmanovi v Boskovicích z 5. února 1890; tamtéž, fol. 697, 698; osobní list správce Okresního hejtmanství v Poličce okresnímu hejtmanovi v Boskovicích ze 14. dubna 1890. 
a dienstfreundlichst, které tvoří součást formulačního jádra písemnosti; dosti často ovšem bývají, zejména v posledních dvou desetiletích 19. století, vynechány. Vlivem odbourávání formalit se mění formulační jádro nót na prosté ich ersuche, neosobní man ersucht nebo pasivní wird ersucht apod. Zmiňuje-li okresní úřad nótu koordinovaného úřadu, na niž odpovídá, náleží jí př́ivlastek geschätzt (např. „Mit Beziehung auf die geschätzte Note vom ... Z[ahl]....").

Nóty jsou, stejně jako většina ostatních komunikační písemnosti, psány bud' na dvojlistu, nebo listu o standardních rozměrech. V pravém horním rohu na první straně je nadepsáno číslo jednací písemnosti. V čele písemnosti se nachází slovo Note, za nějž je občas psán vykřičník. Hned pod kontextem je připojena datační formule, na samostatném řádku pak předpodpisová formule a pod ní je umístěn vlastnoruční podpis okresního hejtmana nebo jeho zástupce. Někdy předchází datační formuli slova $K$. $k$. Bezirkshauptmannschaft, takže udání místa je de facto pokračováním označení úřadu. ${ }^{33}$ Toto označení úřadu se v komunikačních písemnostech boskovického úřadu častěji vyskytuje teprve od 90. let 19. století. V levém dolním rohu na straně, kde nóta končí, se nachází vnitřní adresa v akuzativu (např. „An die löbliche k. k. Bezirkshauptmannschaft in Znaim“).

Nóty se vyskytují i v uzavřené formě, kdy je písemnost na rubu, nebo na poslední straně opatřena vnější adresou $\mathrm{v}$ akuzativu směřující kolmo na vnitřní text a otiskem úředního razítka, nahrazeného už v průběhu 70. let 19. století prostým razítkem označujícím pouze vydavatele písemnosti. K uzavření složené písemnosti dochází zalepením.

\subsection{Listy}

Ačkoliv úřední instrukce z roku 1855 předepisovala pro komunikaci okresních představených s šéfy koordinovaných úřadů tzv. listy, není jasné, zda byly po roce 1870 ještě užívány. Relevantní popis vnitřních a vnějších znaků znemožňuje fakt, že tyto písemnosti, pokud byl jejich původcem boskovický úřad, jsme dosud nalezli výhradně v konceptech. Pokusíme se proto alespoň o analogii na základě čistopisů písemností úřadu (okresnímu hejtmanovi) došlých.

Společným rysem zachycených písemnosti, kterými komunikují šéfové koordinovaných úřadů, je stylizace v 1 . osobě singuláru, dále nepř́imé oslovování adresáta v textu dle stavovské titulatury (např. „Ich beehre mich Euer Hochwohlgeboren mitzuteilen ... “) a užití kurtoazní formule (např. „Genehmigen Euer Hochwohlgeboren den Ausdruck meiner besonderen Hochachtung “) navazující na text sdělení. Tyto písemnosti bývají psány zásadně na dvojlistu. Stejně jako u nót je v pravém horním rohu na první straně uvedeno číslo jednací; datační a předpodpisová formule rozdělené do dvou řádků jsou (ve většině případů) připojeny za text. Funkci ověřovacího prostředku plní vlastnoruční podpis šéfa úřadu. ${ }^{34}$

Zachycené písemnosti se značně liší v umístění a podobě vnitřní adresy. V čele písemností nebývá umístěno stavovské oslovení adresáta. Nahrazuje je vnitřní adresa v dati-

33 Tato provázanost označení úřadu a určení místa a data je patrná ještě v komunikačních písemnostech okresních správ politických z 1. poloviny 20. let 20. století.

34 Podpis hejtmanova zástupce u listů a osobních listů (viz níže) zřejmě nepřicházel v úvahu. 
vu respektující stavovskou titulaturu (např. „Seiner Hochwohlgeboren dem Herrn k. k. Bezirkshauptmann in Boskowitz“), ta však může být umístěna stejně jako u nót v levém dolním rohu na straně, kde končí text písemnosti.

Některé písemnosti obsahují vnitřní adresu v akuzativu, která může být situována oběma výše zmíněnými způsoby. Pak vystupuje v roli adresáta úřad, nikoliv jeho šéf. Takové písemnosti naplňují charakteristiku přípisů. ${ }^{35}$

\subsection{Osobní listy}

Tento druh písemností je nástrojem korespondence okresního hejtmana jakožto šéfa úřadu v úředních záležitostech. Adresát může být výše postavený, na stejné hodnostní úrovni nebo níže postavený, nicméně o vztah podřízenosti a nadřízenosti v pravém smyslu se zpravidla nejedná. Tento typ písemnosti se vyskytuje poměrně zřídka, v důsledku čehož nemáme zatím k dispozici potřebný počet čistopisů, zejména ne těch, jejichž původcem by byl okresní hejtman v Boskovicích.

Z typologického hlediska bychom mezi ně mohli počítat i osobní zprávy, jimž byla věnována pozornost výše, které ale navíc obsahují rubrum. Jinak o osobních zprávách platí z hlediska formuláře, úpravy i stylizace mutatis mutandis totéž, co zaznělo právě u osobních zpráv. Míra kurtoazie snad mohla do jisté míry kolísat v závislosti na hodnostním postavení odesílatele ve vztahu k adresátovi.

Na základě dosavadního výzkumu jsou nám známy př́ípady, kdy okresní hejtman prostřednictvím osobních listů komunikoval s šéfem prezidiální kanceláře moravského místodržitelství nebo šéfem koordinovaného úřadu.

Tento nebo podobný typ písemnosti užíval hejtman rovněž při dožádáních na některé významné osobnosti politického, kulturního života apod. O podobě osobních listů adresovaných některým významným osobnostem jsme schopni momentálně říci pouze to, že v čele písemnosti stálo stavovské oslovení a př́ítomná byla předpodpisová kurtoazie.

\section{Písemnosti pro podřizené př́ijemce}

\subsection{Základní typy písemností a jejich pojmenování}

Úřední instrukce č. 52/1855 ř. z. zná dva základní druhy písemností určených pro podřízené prř́jemce, a sice dekrety (Decrete) a výměry (Bescheide). S oběma těmito názvy se setkáváme u okresních úřadů po celou 2. polovinu 19. století, ba i ve 20. století. Ve 2. polovině 19. století se však velmi často objevuje pro písemnosti určené podřízeným příjemcům označení jiné, totiž výnos (Erlass). Abychom mohli bezpečně identifikovat, jaké typy písemnosti se pod danými názvy skutečně skrývají, musíme se vydat do doby před vznikem okresních politických úřadů - do 1. poloviny 19. století. V následujícím výkladu 
čerpáme z pojednání Josefa von Sonnenfelse, ${ }^{36}$ Maximiliána rytíře von Obentrauta ${ }^{37}$ a tolikrát již uváděné úřední instrukce.

Ze Sonnenfelsovy příručky, jejíž první vydání spatřilo světlo světa roku $1784,{ }^{38}$ se dozvídáme, že již v 80 . letech 18 . století vydávaly politické úřady pro podřízené příjemce dva základní typy písemností - dekrety a výměry. Zatímco dekrety byly vyhotovovány zásadně na samostatném listu a splňovaly některé další formální znaky, měly výměry formu indorzátů psaných zpravidla na rubní, respektive poslední stranu došlé písemnosti a typická pro ně byla jednoduchá, až strohá stylizace za užití pasivní konstrukce. V případě vyřízení došlého podání výměrem se toto zároveň vracelo žadateli.

Výraz výnos (Erlass) se v úřední instrukci č. 52/1855 ř. z. objevuje jako souhrnné pojmenování pro všechny komunikační písemnosti určené př́ijemcům na roveň postaveným nebo podřízeným, to znamená pro veškeré druhy těchto písemnosti vyjma zpráv. ${ }^{39}$ Toto pojetí odpovídá definici výnosů v širším smyslu, jak ji uvádí Obentraut. ${ }^{40} \mathrm{~V}$ užším smyslu jsou pod termínem výnos chápány písemnosti vydávané nadřízeným úřadem úřadu bezprostředně podřízenému obsahující sdělení výsledku úřední činnosti onoho nadřízeného úřadu. ${ }^{41} \mathrm{~V}$ zásadě se jedná o nařízení nebo rozhodnutí, jež mohou být vydávána prostřednictvím vícero druhů písemností. Úřední instrukce v tomto významu užívá termínu nařizeni (Verordnung).

Sonnenfels a Obentraut rozlišují ve svých příručkách tytéž základní typy písemností určených podřízeným př́ijemcům, které uvádí úřední instrukce. Můžeme tedy předpokládat, že písemnosti vydávané okresními úřady po roce 1850 budou navazovat na dekrety a výměry z 1 . poloviny 19 . století.

Většina komunikačních písemností psaných po celé šířce na samostatném listě, určených podřízeným příjemcům se od klasických dekretů poněkud liší. Vedle objektivní stylizace se zcela běžně vyskytuje subjektivní stylizace. Tyto písemnosti se dále vyznačují tím, že adresát není v textu nikdy jmenován plným jménem, často chybí jakýkoliv odkaz na adresáta. Uvádění adresáta v textu nebylo nutné, protože písemnost obsahuje vnitřní adresu v levém dolním rohu na straně, kde končí text písemnosti. Je-li písemnost určena soukromé osobě, užívá se onikání (v němčině) nebo vykání (v češtině). U otevřené formy chybí otisk úředního razítka, u formy uzavřené jsou řádky vnější adresy orientovány

36 Sonnenfels, Joseph von: Über den Geschäftsstyl. (Die ersten Grundlinien für angehende österreichische Kanzleybeamten). Wien $1820^{4}$.

http://archive.org/stream/berdengeschftst00sonngoog\#page/n5/mode/2up, citováno 21. 11. 2017.

37 Obentraut, Maximilian Ritter von: Grundsätzlicher Leitfaden für angehende junge Beamte in praktischen Umrissen. Prag 1865.

http:/ /books.google.cz/books?id=JOOV3_ipkH8C\&pg=PP5\&hl=cs\&source=gbs_selected_pages\&cad=2\#v=0nepage\&q\&f=false, citováno 21. 11. 2017.

38 Sonnenfels, Joseph von: Über den Geschäftsstil. (Die ersten Grundlinien für angehende österreichische Kanzleybeamten). Wien $1784^{1}$.

http://archive.org/stream/bub_gb_Y8tOAAAAcAAJ\#page/n5/mode/2up, citováno 5. 12. 2017.

39 Srov. $\$ 100$ úřední instrukce.

40 Obentraut, M. Ritter von: Grundsätzlicher Leitfaden, s. 50.

41 Tamtéž. 
kolmo na vnitřní text, jako tomu bývá u misiv. ${ }^{42}$ Vosková ani papírová pečet ve funkci uzavírací se již v této době u písemností vydávaných boskovickým úřadem nevyskytují. K uzavření složené písemnosti dochází zalepením. Pro přesnost budiž ještě uvedeno, že u uzavřené formy v průběhu 70. let 19. století nahrazuje otisk úředního razítka s malým státním znakem a s názvem úřadu v obou zemských jazycích v opise, situovaný v blízkosti vnější adresy, prosté razítko, které pouze uvádí název vydavatele. ${ }^{43}$ Tyto písemnosti označované současníky jako výnosy - funkčně nahradily původní zavřené dekrety.

Na základě výše uvedených charakteristik se výnosy jeví jako jakési zjednodušené, méně formální dekrety. Toto zjednodušení se projevuje rovněž absencí uvedení adresáta $\mathrm{v}$ textu písemnosti. V konceptech komunikačních písemností určených soukromým osobám lze v průběhu 70. let 19. století sledovat postupné prosazení onikání (vykání) bez jmenování adresáta v textu na úkor výše popsaných stylizačních zásad typických pro dekrety. Jelikož však nedisponujeme čistopisy těchto písemností, natožpak písemností starších z 50. či 60. let, nemůžeme o nich říci nic bližšího; nevíme, jak vypadaly, a tudíž nejsme schopni posoudit, zda šlo o dekrety, nebo výnosy. ${ }^{44}$ Tento poněkud rozkolísaný úzus ve stylizačních zásadách by však mohl být jedním z příznaků transformace původních (zavřených) dekretů užívaných dříve v obecné úřední komunikaci v ještě jednodušší (a méně vyhraněnou) formu výnosu. ${ }^{45}$

Jisté problematičnosti termínu výnos jsme si vědomi. Jak jsme měli možnost pozorovat, ve 2. polovině 19. století se pod tímto označením skrývá vcelku pestrá škála písemností od formálně zjednodušených dekretů (tj. výnosů, jak jsme je definovali výše), přes oběžníky, dorzální dekrety, ${ }^{46}$ až po písemnosti ve formě listu určené podřízenému příjemci užívané v komunikaci mezi šéfy úřadů, ${ }^{47}$ což ostatně koresponduje s výše uvedenou definicí výnosů v užším smyslu dle Obentrauta.

Dalším typem písemnosti určeným pro podřízené příjemce - kromě dekretů -, jejž pro okresní úřady předepisuje úřední instrukce č. 52/1855 ř. z., jsou výměry. Ze znění příslušných pasáží § 90 a 100 vyplývá, že jsou takto nazývány dorzální dekrety, jejichž prostřednictvím se žádosti podané stranami schvalují, zamítají, vracejí k opravě nebo jinak vyřizují. ${ }^{48}$ Již v 70 . letech 19 . století jsou takto označována písemná vyřízení podaných žádostí bez ohledu na formu písemnosti, častěji však výnosy (ve smyslu zjednodušených dekretů). Formu indorzátu jsme přitom zaznamenali jenom u předběžných vyřízení

42 Viz Sviták, Z.: Z počátků moderni byrokracie, s. 447-450, kde autor popisuje tzv. dekretálni misivy.

43 Toto označení vydavatele není nikdy psáno ručně.

44 Např. SOkA Blansko, OÚ Boskovice, kart. 125, fol. 266v; koncept z 21. října 1870; tamtéž, kart. 126, fol. 336v; koncept z 11. září 1876. V citovaných písemnostech určených soukromým osobám je adresát jmenován již v textu a hovoří se o něm ve 3 . osobě. Ve stejné době se však setkáváme v analogických případech s přímým oslovováním adresáta prostřednictvím osobního zájmena.

45 Srov. Sviták, Z.: Z počátků moderni byrokracie, s. 450.

46 Oběma typům písemností věnujeme pozornost níže na př́slušných místech.

47 Písemnosti ve formě listu, jejichž prostřednictvím komunikuje ministr vnitra (státní ministr) s moravským místodržitelem, jsou v písemnostech, jež se na ně odvolávají, běžně nazývány jako výnosy. Např. MZA, B 13, sg. 2/3, kart. 730, fol. 743; koncept odpovědi, datovaný 4. ledna 1865, na list státního ministra. 
žádosti, kdy je žadatel zpravidla žádán o dodání chybějící přílohy. Konečná vyřízení podaných žádostí mají bez výjimky formu výnosu, i když bývají označována jako výměry. ${ }^{49}$ Indorzáty, psané obvykle na rubní, respektive poslední straně došlé písemnosti, slouží především k udělování konkrétních příkazů podřízeným úřadům v souvislosti s přeposílaným spisem.

$\mathrm{S}$ termínem výměr ve výše uvedeném smyslu nelze pracovat, nebot nejenže (v námi sledovaném období ovšem!) neodpovídá konkrétní formě, nýbrž se postupem času ujímá pro určitý obsahově-právní typ formy zcela jiné, a sice výnosu, pokud je tento vyřízením podané žádosti. Navrhujeme proto pro dorzální obdobu dekretu v souladu s Obentrautem, který už zřejmě reaguje na změněné chápaní termínu výměr, pojmenování dekretace (Dekretation). ${ }^{50}$

\subsection{Výnosy}

Výnosy, ať už otevřené, nebo zavřené, bývají psány na listu nebo dvojlistu a zachovávají celkem jednoduchou formu. V pravém horním rohu na první stránce je napsáno číslo jednací písemnosti. Pod kontextem jsou připojeny stejně jako u zpráv a nót datační a předpodpisová formule a vlastnoruční podpis šéfa úřadu nebo jeho zástupce. Pokud jde o př́itomnost označení úřadu (K. k. Bezirkshauptmannschaft), platí totéž, co bylo řečeno výše u nót. ${ }^{51} \mathrm{~V}$ levém dolním rohu na straně, kde končí text písemnosti, je umístěna vnitřní adresa.

Zavřené výnosy bývají navíc opatřeny vnější adresou, jejíž řádky směřují kolmo na text vnitřní písemnosti. ${ }^{52}$ Tento způsob expedice byl volen u některých nařízení adresovaných podřízeným příjemcům, jež nebyla doprovázena žádnou přílohou. Nějaká pevná pravidla se nám v tomto ohledu nepodařilo vysledovat, rozhodnutí zřejmě záleželo na expeditorovi. Přesto lze vyslovit názor, že důležitější vyhotovení byla expedována v obálce a postrádala vnější adresu.

Ve výnosech se setkáváme s objektivní i subjektivní stylizací. Výnosy obsahující nařízení pro podřízené úřady (především četnické stanice, berní úřady) jsou stylizovány převážně objektivně za užití pasivní konstrukce (nap̌r. „Das k. k. Gendarmeriepostencommando wird aufgefordert ...") a jejich jazykem byla až do zániku Rakousko-Uherska skoro

49 Srov. Sonnenfels, J. von: Über den Geschäftsstyl, s. 109-117. Autor zde v tomto smyslu výměry dělí na předběžné (Vorbescheide) a konečné (Endbescheide).

50 Obentraut, M. Ritter von: Grundsätzlicher Leitfaden, s. 57-58.

51 U dvou výnosů $(1871,1875)$ a jedné nóty (1868) se nám podařilo zachytit nadpis „Von der k. k. Bezirkshauptmannschaft“v záhlaví písemnosti. § 98 úřední instrukce č. 52/1855 ř. z. v této souvislosti uvádí, že každý čistopis má být na konci opatřen formulí „Vom k. k. Bezirksamte zu ... “s uvedením lokality.

52 Tato okolnost vyvolává otázku, jaký je poměr těchto výnosů k někdejším dekretálním misivám (jež byly pro 2. polovinu 18. století popsány u nejvyššího zeměpanského úřadu na Moravě v letech 1748-1782 - viz pozn. 42), a to tím spíše, že u některých písemností boskovického úřadu určených pro podřízené př́ijemce bývá už v 50. letech 19. století vnitřní adresa umístěna v čele písemnosti, jak to bývalo dříve typické pro oslovení adresáta právě v misivách. Ve 2. polovině 19. století jsou však některé komunikační písemnosti již natolik zbaveny někdejších typických, rozlišovacích znaků, že odpovědět jednoznačně na tuto otázku není snadné. 
výhradně němčina. Naproti tomu jsou výnosy adresované obecním a městským radám běžně v češtině a mnohdy bývají stylizovány v 1. osobě singuláru (např. „Vybizím obecni predstavenstvo, aby mi ve třech dnech oznámilo ... "); s touto subjektivní stylizací se lze setkat i ve 20. letech 20. století. V českých výnosech se běžně užívá pasivního imperativu (např. „Budiž sem podána zpráva ... “), méně často se vyskytuje aktivní imperativ (např. „Vyšetřete do 8 dnů, zda ...").

Taktéž rozhodnutí o podaných žádostech zlistiňovaná formou výnosů mohou být stylizována jak objektivně (jménem úřadu nebo pomocí pasivní konstrukce), tak subjektivně (jménem okresního hejtmana) s tím, že na česká podání úřad už v 70. letech 19. století odpovídá většinou česky. Tyto výnosy se zpravidla odvolávají na podání, jež se jimi vyřizuje.

Některé otevřené výnosy jsou navíc ještě opatřeny otiskem úředního razítka. Tak tomu bylo zejména pokud se jimi udělovalo nějaké povolení, dispens apod. Pokud je nám na základě dosavadního výzkumu známo, bývaly vydávány výhradně soukromým osobám a adresát je v nich jmenován přímo v kontextu. Stylizovány mohly být objektivně i subjektivně. Zatím se nám nepodařilo určit, zda tyto písemnosti navazují na nějaký starší typ, nebo jde pouze o „honosněji“ vybavené výnosy. Jejich podoba, jak jsme ji dosud ve spisovém materiálu zachytili, hovoří spíše pro druhou variantu. Spolehlivě však může tuto otázku objasnit jedině další výzkum.

V 70. letech 19. století jsme u některých výnosů odpovídajících bezprostředně na žádost soukromých osob zaznamenali vyznačení předmětu, o němž písemnost pojednává. Tento údaj bývá uveden v levém horním rohu na první straně výnosu a obsahuje jméno adresáta a záležitost, v níž se žadatel na úřad obrací. Jedná se o doslovný opis rubra žádosti vyjma oslovení úřadu. Koncept takové písemnosti je na samostatném řádku uvozen slovy ad copiam rubri. Tyto výnosy jsou vyhotovovány na samostatném listě a je pro ně typická jednoduchá stylizace za užití pasivní konstrukce. Tuto formu mohou mít i výnosy, jimiž se schvalují podané žádosti. ${ }^{53}$

Od 80. let 19. století už v textu písemnosti adresát obvykle nebývá jmenován plným jménem. U výnosů pro podřízené úřady napřríklad schází uvedení lokality (sídla př́íslušného úřadu), nebo odkaz na adresáta zcela chybí; pak je kontext pouhou formulací nařízení. Plný název adresáta nalezneme vždy ve vnitřní adrese. U výnosů určených soukromým osobám se podle jazyka vyřízení adresátovi bud' oniká, nebo vyká. V případě odkazu na podání jsou většinou užívána příslušná přivlastňovací zájmena (např. „... nemůže býti Vaši žádosti vyhověno. "). Je-li adresátem výnosu představený podřízeného úřadu je oslovován nepř́ímo, takže se o něm hovoří ve 3 . osobě (např. „Pan starosta se vybizi, aby ... “).

Jak vidno, prostřednictvím výnosů mohou být zlistiňovány různé obsahy: nařízení pro jakékoliv podřízené nebo níže postavené příjemce i rozhodnutí o podaných žádostech. Obsahově-právní charakter výnosů se tak pohybuje od př́kazů podřízeným úřadům až k dispozitivním listinám vydaným na základě podané žádosti. Tuto dvojakost odráží i dobové rozlišování komunikačních písemností vydávaných z titulu nadřízenosti na výnosy a výměry, jež nemá z diplomatického hlediska opodstatnění. ${ }^{54}$

53 Kontext takového výnosu pak zní třeba jen „wird bewilligt“.

54 Toto můžeme bezpečně tvrdit pouze pro období do konce 19. století. Pro pozdější léta (do roku 1928) máme k dispozici jen omezený počet čistopisů písemností s povahou dispozitivních listin. 


\subsection{Oběžníky a kurendy}

V § 90 úřední instrukce pro okresní úřady z roku 1855 se praví, že má-li být nějaké nařízení zprostředkováno většímu okruhu podřízených úřadů, mají být vyhotoveny dekrety ve formě oběžných listů (Umlaufschreiben), kurend (Currenden) nebo cirkulářu (Circularien). Z př́íslušného ustanovení instrukce není zcela jasné, zda jsou všechna tři pojmenování synonymní, nebo jestli označují různé druhy písemností. Obentraut se v tomto smyslu zmiňuje o cirkulářích (Zirkularien), okružních listech (Kreisschreiben), oběžných listech (Umlaufschreiben) a kurendách (Kurrenden) a tvrdí, že jsou tyto názvy v podstatě souznačné. To není tak zcela pravda, jelikož u oběžných listů a kurend zmiňuje jako specifikum, že bývají vyhotoveny v jednom exempláři, který si adresáti předávají, a nakonec se vrací zpět vydávajícímu úřadu. ${ }^{55}$ Sonnenfels zmiňuje cirkuláře (Circularien), ${ }^{56}$ které však funkčně odpovídají kurendám v Obentrautově pojetí a konečně i v podobě, v jaké jsme se s nimi setkali ve spisech okresního politického úřadu v Boskovicích. Mezi komunikačními písemnostmi okresního úřadu určenými většímu počtu podřízených úřadů se nám podařilo identifikovat dvě odlišné formy.

První typ reprezentují písemností, které se od výnosů užívaných v obecné úřední komunikaci liší pouze hromadnou vnitřní adresou (Vร̌em obecním představenstvưm!) a tím, že mají zpravidla formu rozmnoženiny. Tyto písemnosti bývají v literatuře standardně nazývány jako oběžniky a není důvodu, proč se tohoto vhodného označení nepřidržet. ${ }^{57}$ Dlužno poznamenat, že úřady samotné užívají k jejich označení spíše termínu výnos (Erlass). Obentrautovy a Sonnenfelsovy popisy svědčí o tom, že oběžníky zčásti plní funkci někdejších cirkulářù, zdá se ale, že po formální stránce jsou oběžníky odlišným typem písemnosti odvozeným nejspíš z výnosů.

Dalším typem jsou písemnosti vyhotovované v jednom exempláři, který si měly podřízené úřady předávat za současného provedení ukládaných pokynů. Jedná se o kurendy. Toto označení (Currende) se objevuje v čele písemnosti. Vzhledem k zcela nedostatečnému počtu shromážděných čistopisů upouštíme od zevrubnějšího popisu vnějších a vnitřních znaků.

\section{Indorzáty a rubrální zprávy}

Zprávy, nóty, přípisy a dekrety mají své dorzální protějšky. Tyto indorzáty bývají zpravidla psány na rubu, resp. poslední straně došlé písemnosti, nebo na samostatném listě či dvojlistě, a to bud' po pravé, nebo levé polovině strany. List je podélně přeložen na poloviny (u dvojlistu není potřebné) a přeposílaná písemnost je vložena do takto vzniklého obalu.

Od úředních písemností psaných po celé šířce samostatného listu se indorzáty liší celkově stručnou stylizací; typické je pro ně užití pasivní konstrukce (např. „Wird dem

55 Obentraut, M. Ritter von: Grundsätzlicher Leitfaden, s. 104-105.

56 Sonnenfels, J. von: Über den Geschäftsstyl, s. 142-143.

57 Srov. Šmilauerová, E.: Správni vývoj a diplomatika, s. 157. 
hochlöblichen Statthalterei Praesidium ... ergebenst vorgelegt. “) a jmenování adresáta v dativu př́imo v textu. Jak již bylo řečeno výše, dorzální dekrety (a jejich prostřednictvím i ostatní indorzáty) jsou v podstatě odvozeny z inskripční formule (inskripce) dekretů. ${ }^{58}$ Nejjednodušší forma indorzátu postrádá větný přísudek (např. „Dem k. k. Gendarmerie Posten Commando in Oels zur umgehenden Erhebung und Berichterstattung binnen 5 Tagen. "). Označení adresáta $\mathrm{v}$ dativu často mívá pro přehlednost formu nadpisu rozděleného do několika řádků a vytváří pak dojem vnitřní adresy. U indorzátů zasílaných koordinovaným úřadům se někdy v čele písemnosti objevuje nadpis Note. Indorzáty jsou zakončeny datační formulí, úředním titulem podepisujícího úředníka a vlastnoručním podpisem okresního hejtmana nebo jeho zástupce. Indorzáty bývají zpravidla psány přímo vyřizujícím úředníkem (referentem), ale běžně se vyskytují i kancelářská vyhotovení, jimž předcházel koncept. Číslo jednací je bud' nadepsáno referentem, případně mundátorem, nebo jeho funkci plní číslo jednací poznamenané na rub došlé písemnosti na podatelně.

Indorzáty mají v zásadě přeposílací či doprovodnou funkci ve vztahu k písemnosti, na jejímž rubu se nacházejí. Jejich prostřednictvím lze například zasílat došlé žádosti nebo místodržitelské výnosy podřízeným úřadům k podání zprávy, zasílat došlé písemnosti k vyjádření (podání dobrozdání) úřadům koordinovaným nebo postupovat nadřízenému úřadu vypracovaný jednací spis.

Prvotní formu indorzátu pravděpodobně představují dorzální dekrety. Ty rozeznává jako samostatný druh písemnosti ve své obsáhlé monografii věnované nejvyššímu zeměpanskému úřadu na Moravě v letech 1748-1782 Zbyněk Sviták. Nazývá je po vzoru dobového úzu dekretace. ${ }^{59}$ Josef von Sonnenfels ve svém pojednání zachycujícím stav po roce 1781, kdy byly dvorským dekretem ze 22. prosince téhož roku stanoveny nové zásady za účelem zjednodušení úřední korespondence, ${ }^{60}$ nazývá dorzální obdobu dekretů jako výměry. ${ }^{61}$ Srovnáme-li Svitákovy charakteristiky dekretací se Sonnenfelsovým popisem výměrů, dojdeme k závěru, že výměry vývojově navazují na dekretace, i když se oba typy písemností do jisté míry liší po formální i funkční stránce. Dekretace plnily funkci vnitř̆ních písemností, pokud jimi byly udělovány př́ikazy nižšímu úřednictvu (např. expeditorovi), nebo mohly být expedovány, a v takovém případě lze hovořit o funkci doprovodné či přeposílací. ${ }^{62}$ Podobné, ale ještě širší využití měly i výměry, jejichž prostřednictvím mohlo být (za určitých okolností) zlistiněno jakékoliv nařízení nebo rozhodnutí úřadu směřující na podřízené př́jemce. $\mathrm{V}$ podobném duchu jako u Sonnenfelse je termín výměr (Bescheid) užíván i v úřední instrukci pro okresní úřady z roku $1855 \mathrm{~s}$ tím rozdílem, že se v ní výslovně nezmiňují výměry ve funkci vnitřní písemnosti. Jak jsme uvedli výše v jiné souvislosti, užívá Obentraut v pojednání z roku 1865 pro někdejší výměry název dekretace, což je patrně způsobeno posunem významu termínu výměr.

58 Srov. Sviták, Z.: Z počátků moderni byrokracie, s. 450.

59 Tamtéž, s. 454-460.

60 Zmínka o dvorském dekretu např. tamtéž, s. 441.

61 Sonnenfels, J. von: Über den Geschäftsstyl, s. 104-119.

62 Sviták, Z.: Z počátků moderni byrokracie, s. 457, 460. 
Již u Sonnenfelse se dočítáme o možnosti dorzální korespondence s úřady postavenými na roveň pomocí indorzací (Indossationen). ${ }^{63}$ Funkcí i stylizací tyto písemnosti v podstatě odpovídají indorzátům pozdějších okresních úřadů. Obentraut užívá v půli 60. let 19. století pro indorzát určený koordinovaným úřadům označení dorzálni nóta (Indorsatnote). ${ }^{64}$

Obentraut konečně zmiňuje i dorzální zprávy (Indorsatberichte), o nichž sice soudí, že nejsou vhodné pro písemný styk podřízeného úřadu s nadřízeným, nebot nejsou v souladu s úctou, již má podřízený úřad úřadu nadřízenému prokazovat, nicméně uvádí, že je jejich užívání dovoleno a praktikováno. ${ }^{65}$

Námi zvolená pojmenování vcelku korespondují s názvy užívanými Obentrautem. Indorzáty dělíme dle hodnostního hlediska na dorzální zprávy, dorzální nóty (pouze pokud jsou nadepsány slovem Note) či dorzální přípisy a dekretace (dorzální dekrety). Indorzáty jako celek tvoří svébytnou formu a nutno poznamenat, že výrazy dorzálni zpráva, dorzálni nóta a dorzálni přípis samy o sobě nevypovídají o formě písemnosti, která je odvozená z dekretace jakožto dorzálního dekretu.

Ve formě rubopisu byly vyhotovovány také tzv. rubrální zprávy vzniklé rozšířením dispoziční části rubra. Rubrální zprávy bývají psány zásadně na samostatném listě nebo dvojlistě (na jeho poslední straně) po pravé polovině stránky. Zachovávají formulář i stylizaci rubra. Do roku 1908, kdy zanikají (viz níže), plnily často funkci doprovodných zpráv, jindy referent zvolil tuto formu pro kratší sdělení nadřízenému úřadu.

\section{Proměny komunikačních písemností na přelomu 19. a 20. století}

\subsection{Popis proměn}

V rozmezí let 1899 až 1908 prošly formální úprava a stylizace komunikačních písemnosti tehdejších okresních hejtmanství proměnami, díky nimž získaly novou, moderní podobu typickou pro 1. polovinu 20. století. Projevy počínajících změn jsou patrné u písemností jednotlivých okresních hejtmanství v nestejné míře již od 80. let 19. století.

Přelomovým byl rok 1899. Oběžníkem prezidia moravského místodržitelství č. 1122 ze dne 16. února 1899 byli všichni okresní hejtmani, starostové statutárních měst, ředitel brněnského policejního ředitelství a šéf Policejního komisariátu v Moravské Ostravě informováni o nových pravidlech formální úpravy a stylizace komunikačních písemností; cílem bylo zjednodušení úředního písemného styku. Právním předpisem, který upravoval tyto změny (a na nějž se oběžník odvolává) byl výnos ministra vnitra č. j. 9574 z 15. ledna 1899. Na základě zde vytčených zásad došlo k:

1) vypuštění kurtoazních výrazů všech typů, tj. jednak z vnitřní adresy a při vzájemném oslovování úřadů (hochlöblich, hoch, löblich), jednak kurtoazních slůvek obje-

63 Sonnenfels, J. von: Über den Geschäftsstyl, s. 139-140.

64 Obentraut, M. Ritter von: Grundsätzlicher Leitfaden, s. 58.

65 Tamtéž, s. 58-59. 
vujících se v kontextu (ergebenst, höflichst, dienstfreundlichst, hoch, geschätzt apod.). Odpadnout měla také stavovská nebo čestná titulatura ve vnitřních adresách, př́ípadně rubrech (např. „An Seinen Excellenz den Herrn ... “; nově pouze „An den Herrn ... "), jakož i kurtoazní formule (např. „Genehmigen Euer Excellenz ... “).

2) Místo a zanedlouho i označení úřadu (K. $k$. Bezirkshauptmannschaft) se společně s datem přesouvá na začátek písemnosti (původně za kontextem), takže tvoří její záhlaví. Číslo jednací písemnosti bývá uvedeno vlevo nahoře pod označením úřadu a datem (původně vpravo nahoře). V této souvislosti oběžník pouze uvádí, že datum zpráv má být umístěno vždy na první straně vpravo nahoře, zatímco číslo jednací vlevo nahoře.

Spolu s popsanými inovacemi dochází již od 80. let 19. století k přesouvání vnitřní adresy v akuzativu do čela písemnosti (původně vlevo dole na straně, kde končí text písemnosti). V průběhu 90 . let se toto stává běžnou praxí. Zároveň z nót postupně mizí nadpis Note umistovaný do čela písemnosti, jejž nahrazuje právě vnitřní adresa. Tyto písemnosti jsou označovány jako př́pisy. ${ }^{66}$ Co se týče dorzálních protějšků nót, respektive př́ípisů, jejich dosavadní forma zůstává zachována. Již od 70. let 19. století jsme zachytili mezi čistopisy komunikačních písemnosti boskovického úřadu výhradně dorzální přípisy, tj. formu bez nadpisu Note, která i u jiných původců zcela převažovala.

Pokud bychom byli odkázáni výhradně na čistopisy dochovaných písemností Okresního hejtmanství v Boskovicích, mohli bychom lehce nabýt dojmu, že přípisy vznikly zjednodušením nót. Nemohlo tomu tak ovšem být, nebot nóty a přípisy existovaly téměř po celé sledované období - dle našeho šetření prokazatelně ještě v 1. polovině 2 . desetiletí 20. století - vedle sebe. ${ }^{67}$ Vedle toho se setkáváme také s určitými mezitypy, u nichž se v čele písemnosti objevuje nadpis Note a zároveň (nad ním) i vnitřní adresa, nebo vnitřní adresa zůstává na svém původním místě, ale chybí nadpis Note. S tímto poněkud rozkolísaným územ souvisí i nejednotnost v pojmenování jednotlivých forem, markantní zejména v poslední čtvrtině 19. století, kdy bývají nóty (a někdy také listy) stále častěji označovány termínem př́pis (Zuschrift), což platí částečně i obráceně. Od 90. let 19. století lze užívání nót vnímat jako projev určitého konzervatismu. Původ a dobu vzniku př́ipisů bude třeba objasnit. ${ }^{68}$

Další výraznou změnu přináší rok 1908. Oběžníkem č. j. 4540 ze dne 24. května 1908 nařídil moravský místodržitel některé změny v úpravě zpráv podřízených úřadů. V souladu s pokyny prezidiálního oběžníku je nově místo dosavadního rubra každá zpráva vlevo pod číslem jednacím opatřena tzv. předmětem (Betreff), který pomocí jednoduchého hesla vystihuje obsah písemnosti. Pod vyznačením předmětu je uváděno (citováno) číslo jednací výnosu nebo oběžníku, na jehož základě se zpráva podává. Odpadá tak úvodní formule zpráv typu „In Befolgung des hohen Erlasses vom ... “. Jsou-li součástí zprávy př́ilohy,

66 V odborné literatuře se termínu přípis mnohdy užívá pro souhrnné pojmenování komunikačních písemností. Srov. citovaná studie Antonína Macáka.

67 Velice dlouho zůstávaly nóty v oblibě u moravského ředitelství pošt a telegrafů (K. k. Post-und Telegraphen-Direktion für Mähren), kde byly prokazatelně užívány ještě v roce 1914.

68 U přípisů jsme ve 20. letech 20. století zaznamenali velmi vzácně stylizaci v 1. osobě plurálu. 
je udán pod citací př́slušného výnosu jejich počet, př́padně je užit výraz Konvolut, česky svazek spisů. Následkem těchto změn zanikají rubrální zprávy.

V oběžníku se uvádí, že vytčené zásady mají být uplatňovány i při korespondenci $\mathrm{s}$ ostatními úřady. $\mathrm{V}$ prŕpisech a výnosech boskovického úřadu se $\mathrm{s}$ těmito údaji (vyznačení předmětu, citace př́ijemcovy písemnosti atd.) setkáváme i ve 20. letech spíše výjimečně.

Konečně je třeba zmínit se ještě o několika dalších změnách.

Přibližně od počátku 90. let 19. století nahrazuje v nótách, respektive př́ípisech, a výnosech vlastnoruční podpis okresního hejtmana nebo jeho zástupce otisk jejich podpisového razítka.

Po roce 1900 se rychle rozšiřuje užívání psacího stroje, v důsledku čehož jsou rukopisná vyhotovení nahrazena strojopisy. Okresní hejtmanství v Boskovicích zakoupilo psací stroj v roce $1906 .{ }^{69}$ Písemnosti se stávají snáz čitelnými a přehlednějǔ́mi (udávání předmětu, odstranění zbytečných výrazů kurtoazní povahy a stereotypních formulí), ale zároveň ztrácejí na vzhlednosti, vyskytují se překlepy. Rozmnoženiny, ponejvíce oběžníky nebo formuláře různých expedovaných písemností, pořizovala kanceláŕ úřadu, a až do roku 1918 měly rukopisnou předlohu, přibližně od počátku 20. let pak strojopisnou. Od poloviny 20. let roste užití předtištěných formulářu komunikačních písemností užívaných v rámci některých stereotypních agend (např. občanské sňatky) z tiskárny Zemské správy politické v Brně.

Po roce 1900 klesá počet komunikačních písemností psaných na dvojlistech na naprosté minimum. U prŕípisů a výnosů se s nimi prakticky nesetkáme. Naproti tomu se častěji než v předešlém období (tj. od počátku 70. let 19. století) užívá polovičních listů o rozměrech $21 \times 17 \mathrm{~cm}$ (píše se na šíŕku) pro kratší přípisy, výnosy nebo oběžníky.

$\mathrm{Z}$ indorzátů se $\mathrm{v}$ době, kdy je už běžně užíván psací stroj, vyděluje zvláštní skupina písemností, jež bývají (vyjma této formy zpráv) psány po celé širrce samostatného listu polovičního formátu o rozměrech $21 \times 17 \mathrm{~cm}$ (píše se na šířku), aniž by ztrácely typický formulář a stylizaci indorzátů (např.: „Berni správě k vyjádřeni“; „Okresni správě politické v Litovli se sdělením, že ... “; „Obecni radě v Protivanově s vybídnutím, aby ... “). Přívlastek dorzálni je v takových př́padech vhodné nahradit adjektivem prưvodni. U písemností tohoto typu proto navrhujeme označení prưvodni zpráva, průvodni prípis a průvodni výnos. Pojmenování indorzátů, kterých se i nadále užívá v hojném počtu, tímto není nijak dotčeno.

Za první republiky se ve zprávách namísto oslovení nadřízeného úřadu uplatňuje vnitřní adresa v dativu stejně jako u ostatních typů písemností.

U některých výnosů, ale i př́ípisů chybí vnitřní adresa v akuzativu (v německy psaných) nebo v dativu (v česky psaných). Po roce 1900 takové písemnosti většinou začínají označením adresáta v nominativu, které je však graficky odděleno od ostatního textu, jako by šlo o skutečnou vnitřní adresu v čele písemnosti (nap̌r. „Obecni prédstavenstvo ve Žd’árné se vybizi, aby ...").

69 SOkA Blansko. OÚ Boskovice, kart. 13, č. j. 89/1908 pres. 


\subsection{Důsledky proměn}

Výše popsaná modernizace a unifikace formální úpravy a stylizace komunikačních písemností má za následek splývání především jejich základních a nejužívanějších druhů, tj. zpráv, přípisů a výnosů.

Nevznikají sice nové písemnosti, dochází však k zásadní modifikaci stávajících forem. Prosazuje se forma přípisu, jež zachovává ten nejjednodušší formulář s vnitřní adresou umístěnou v čele písemnosti. Zatímco u výnosů má tato změna za následek v podstatě pouze jiné umístění vnitřní adresy, zprávy a nóty zasahují proměny mnohem citelněji. Zprávy v důsledku transformace pozbývají charakteristické oslovení adresáta v čele písemnosti, zatímco nóty zcela vycházejí z užívání. Z přísně formálního hlediska už nelze hovořit o zprávách, nótách a výnosech. Existují jen tř̌i nepř́iliš odlišné druhy přípisů.

Nejvyšší míra vzájemného splývání postihuje následkem vypuštění všech kurtoazních prvků přípisy a výnosy, nebot stylizační jádro některých písemností pro podřízené nebo níže postavené příjemce zní dokonce stejně jako u části přípisů: žádá se. Tuto formulaci jsme zaznamenali od 80 . let 19. století také v některých výnosech a oběžnících (prezidia) moravského místodržitelství adresovaných okresním hejtmanům. Zatím se nám nepodařilo objasnit, proč byla v určitých situacích užívána a jaký je její původ (jak v písemnostech místodržitelství, tak okresního hejtmanství). V těchto nejistých případech navrhujeme přidržet se prozatím při pojmenovávání té které písemnosti hodnostního hlediska.

Toto připodobňovaní a splývání do jisté míry kompenzuje jakási honosnost vyhotovení typická především pro zprávy; zprávy musejí být opatřeny vlastnoručním podpisem okresního hejtmana nebo jeho zástupce a zásadně obsahují vyznačení předmětu. Popsané formální náležitosti jsou pro zprávy sice charakteristické, ale bývají přítomny i u některých přípisů a výnosů, nelze s nimi proto pracovat jako se zcela určujícími kritérii pro typologii komunikačních písemností. Po stránce stylizační se pak zprávy, přípisy a výnosy mnohdy liší pouze zněním stylizačního jádra (podává se zpráva; sděluje se; žádá se; nařizuje se). ${ }^{70}$ Jen v některých zprávách a přípisech se užívá kurtoazního slůvka laskavý nebo laskavě (např. „Žádá se o laskavé sděleni ... “). Možnost stylizace těchto písemností v 1. osobě singuláru nebo za pomoci pasivních konstrukcí zůstává zachována, ačkoliv podíl subjektivně stylizovaných písemností u boskovického úřadu významně klesáa. ${ }^{71}$

Pokud jde o ostatní typy komunikačních písemností, lze konstatovat následující: Oběžníky odlišuje především hromadná vnitřní adresa; nejasný je zatím osud kurend, totiž zda byly užívány i v 1 . polovině 20. století. Čistopisy komunikačních písemností ve formě listu a osobního listu nemáme po roce 1900 k dispozici, koncepty pouze vzácně, a to z prvních dvou desetiletí 20. století. Je pravděpodobné, že byly užívány v menší míře než dříve, spíše ve výjimečných případech, jestliže to vyžadovala povaha záležitosti. Zejména někdejší listy mohly být snadno nahrazeny nótami, respektive př́ípisy.

70 Vy̌še citovaný oběžník prezidia moravského místodržitelství č. j. 4 540/1908 dokonce povoloval i vypuštění stylizačního jádra komunikačních písemností (pokud to připadalo v úvahu). S takovými písemnostmi, jejichž původcem by byl okresní politický úřad v Boskovicích, jsme se během našeho dosavadního bádání nesetkali. 


\section{Závěr}

V této studii jsme usilovali o popsání typů komunikačních písemností vydávaných okresním politickým úřadem v Boskovicích v letech 1870-1928 a zachycení proměn, jakož i charakteristických vývojových trendů v rámci této specifické skupiny expedovaných písemností.

Základními kritérii pro stanovení jednotlivých typů písemností jsou hodnostní vztah vydavatele $\mathrm{k}$ př́ijemci, skladba a uspořádání formuláře, celková úprava a způsob vyhotovení písemnosti (per extensum nebo in dorso), znění stylizačního jádra a přítomnost a podoba kurtoazních prvků, v omezené míre i stylizace gramatická.

V korespondenci okresního úřadu můžeme sledovat jistou dvoj až trojkolejnost, kdy kromě písemností vydávaných úřadem jako celkem existují takové, jejichž prostřednictvím komunikuje v úředních záležitostech šéf úřadu se šéfy ostatních úřadů nebo jinými osobami, jež mohou, a nemusejí být úředníky. V nejobecnější rovině tak lze rozdělit komunikační písemnosti na písemnosti úřadu jako celku a ty, jež užívá okresní hejtman jakožto šéf úřadu, totiž listy a osobní listy.

Od 70. let 19. století přibližně do roku 1900 užíval úřad při písemné komunikaci v závislosti na hodnostním vztahu k adresátovi nejčastěji tři základní typy písemností, a sice zprávy, nóty, jež zhruba v 90. letech nahradily př́ípisy, a výnosy. Jde tu o tři zcela odlišné formy různého původu, přičemž výnosy jsou patrně odvozeny ze starších dekretů na základě jejich formálního zjednodušení. Z výnosů jsou odvozeny oběžníky určené zpravidla většímu okruhu podřízených příjemců. K podobnému účelu sloužila i písemnost zvaná kurenda, která však na rozdíl od oběžníku byla vyhotovována v jediném exempláři, který mezi podřízenými př́ijemci koloval. Její původ a vznik bude ještě třeba objasnit. U všech jmenovaných typů písemností (u kurend nedoloženo) připadá v úvahu objektivní i subjektivní gramatická stylizace, což vyplývá z organizace úřadu na monokratickém principu.

Zprávy, nóty, přípisy a dekrety měly dorzální protějšky. Prvotní a určující byla forma dorzálního dekretu (dekretace), již zachovávají všechny ostatní indorzáty. U dorzálních zpráv, nót a přípisů se spřízněnost s protějšky psanými po celé šířce samostatného listu projevuje především ve znění stylizačního jádra. Gramatická stylizace je důsledně objektivní za užití pasivní konstrukce.

Podle úřední instrukce č. 52/1855 ř. z. měl okresní úřad, respektive jeho šéf při korespondenci s šéfy úřadů na roveň postavených nebo s ostatními veřejnými orgány, jež nebyly k okresnímu úřadu ve vztahu služební podřízenosti, užívat listů. Dosud se nám nepodařilo zachytit jediný čistopis tohoto typu písemnosti vydaný boskovickým úřadem. Z dochovaných konceptů se zdá, že listy byly užívány výhradně v písemném styku mezi šéfy koordinovaných úřadů. Užití listu bylo pravděpodobně projevem určité kurtoazie. Po roce 1900 nemáme doklad o výskytu těchto písemností.

V čistopise nemáme zatím doloženy ani osobní listy. Ty byly užívány okresním hejtmanem prokazatelně bez ohledu na hodnostní vztah k příjemci. Zvláštním typem osobního listu jsou osobní zprávy adresované místodržiteli, opatřené po vzoru klasických zpráv rubrem.

Snahy o maximální zjednodušení úřední korespondence a odstranění všech formalit započaté dvorským dekretem z 22. prosince 1781 docházejí definitivního naplnění mezi 
lety 1899 až 1908. Jejich výrazem se stává kromě úprav spíše kosmetického rázu (např̀ uvádění názvu úřadu, místa a data v záhlaví písemnosti) postupné prosazení nejjednodušší formy komunikační písemnosti převzaté z přípisu, což vedlo především k zániku typického formuláře zpráv, zániku rubrálních zpráv a k nahrazení nót přípisy. Indorzáty přetrvávají ve stávající podobě, ale ve chvíli, kdy úřad disponuje psacím strojem, bývají někdy psány po celé šířce na samostatném listě, čímž vznikají nové písemnosti, pro něž jsme zvolili označení průvodni zpráva, průvodni prípis a průvodni výnos. Odklon od některých forem nebo konkrétních typů písemností, jako například listů nebo kurend, spíše předpokládáme, ale vzhledem k omezené pramenné základně jej nelze považovat za dostatečně prokázaný.

Při stanovování názvů jednotlivých písemností jsme se tam, kde to bylo smysluplné nebo věcně správné, drželi dobového úzu. Pro formálně zjednodušené dekrety jsme zvolili označení výnos. Učinili jsme tak s vědomím, že termín výnos neoznačoval ve své době formu, nýbrž obsah. Naproti tomu jsme nepracovali s termínem výměr, jehož význam se v průběhu 19. století měnil a po roce 1850 již označoval obsahově-právní charakter písemnosti, a to výnosu. Pro indorzáty zasílané na roveň postaveným př́ijemcům jsme zvolili název dorzálni př́pis, pokud chybí v čele písemnosti charakteristický nadpis Note, ačkoliv byly tyto písemnosti boskovickým úřadem užívány v 19. století paralelně s nótami. Pro zprávy, př́ípisy a výnosy ponecháváme původní názvy i po roce 1900, přestože zhruba od 2. desetiletí 20. století získávají všechny tři písemnosti téměř jednotný formulář a úpravu.

Závěrem lze shrnout, že typy komunikačních písemností užívaných boskovickým okresním úřadem v letech 1870-1928 v značné míře navazují na typy užívané politickými úřady v 2. polovině 18 . a 1 . polovině 19 . století. V průběhu let prošly některé písemnosti významnou proměnou. Původní zavřené dekrety kupříkladu nahrazují méně formálně vyhraněné výnosy. Formulář a úprava nejužívanějších komunikačních písemnosti jsou kolem roku 1900 zjednodušeny maximálním možným způsobem, a tím i do značné míry unifikovány. U zpráv, přípisů i jejich dorzálních protějšků dochází definitivně k vypuštění všech projevů kurtoazie. 


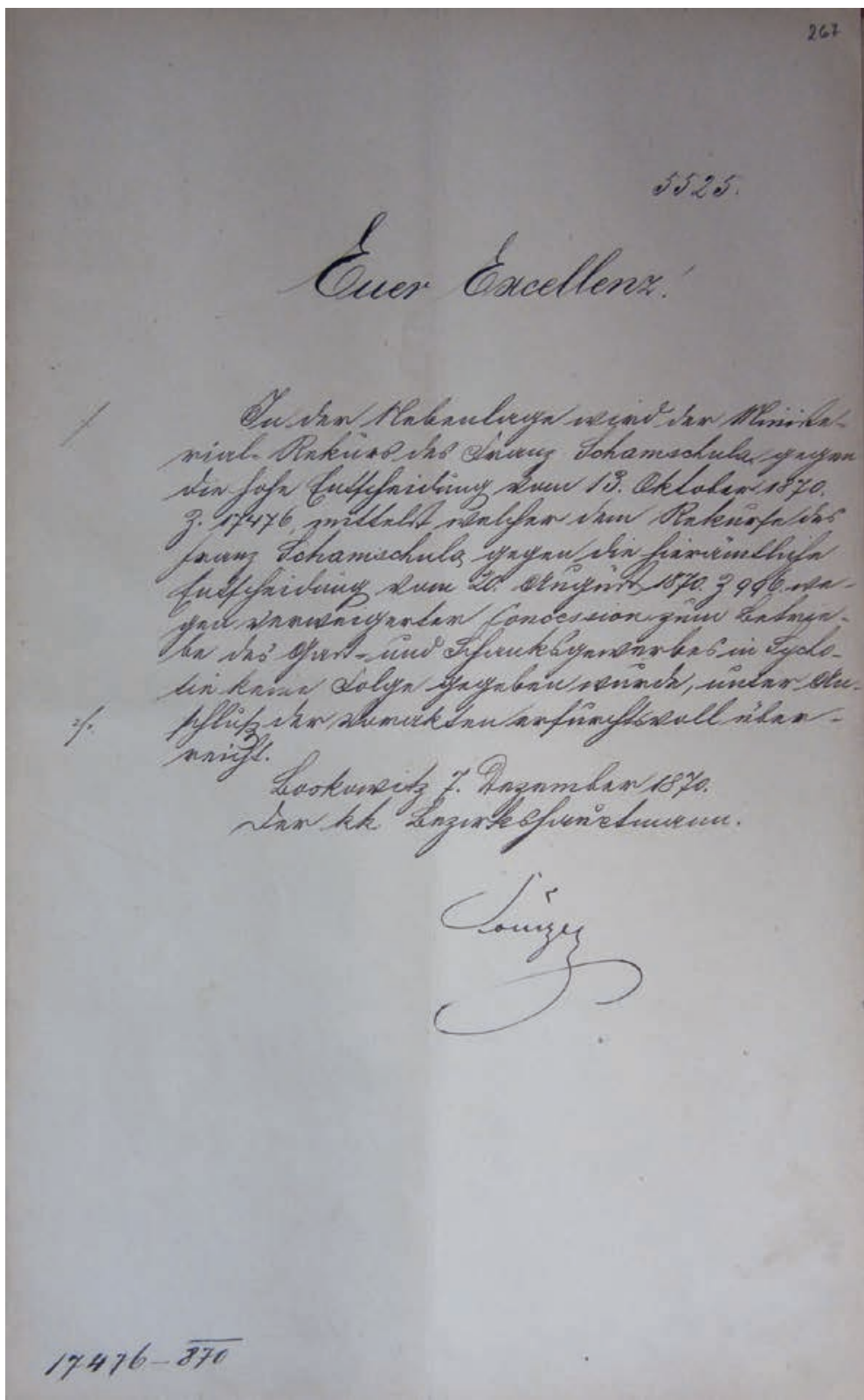

Obr. 1a: První strana zprávy moravskému místodržitelství (SOkA Blansko, fond Okresní úřad Boskovice 1850-1945, kart. 125, fol. 267r) 


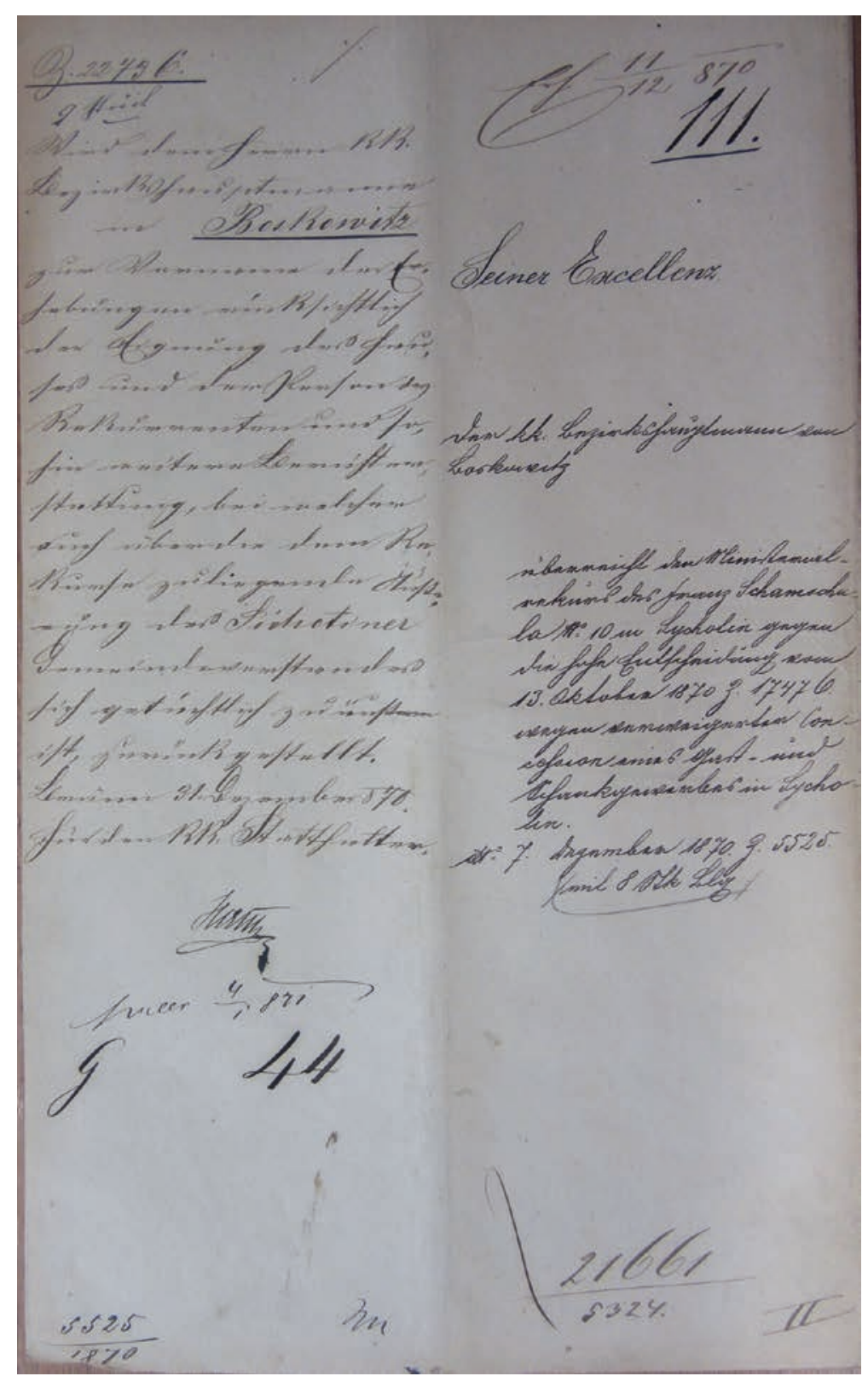

Obr. 1b: Poslední strana téže zprávy (SOkA Blansko, fond Okresní úřad Boskovice 1850-1945, kart. 125, fol. 277v) 


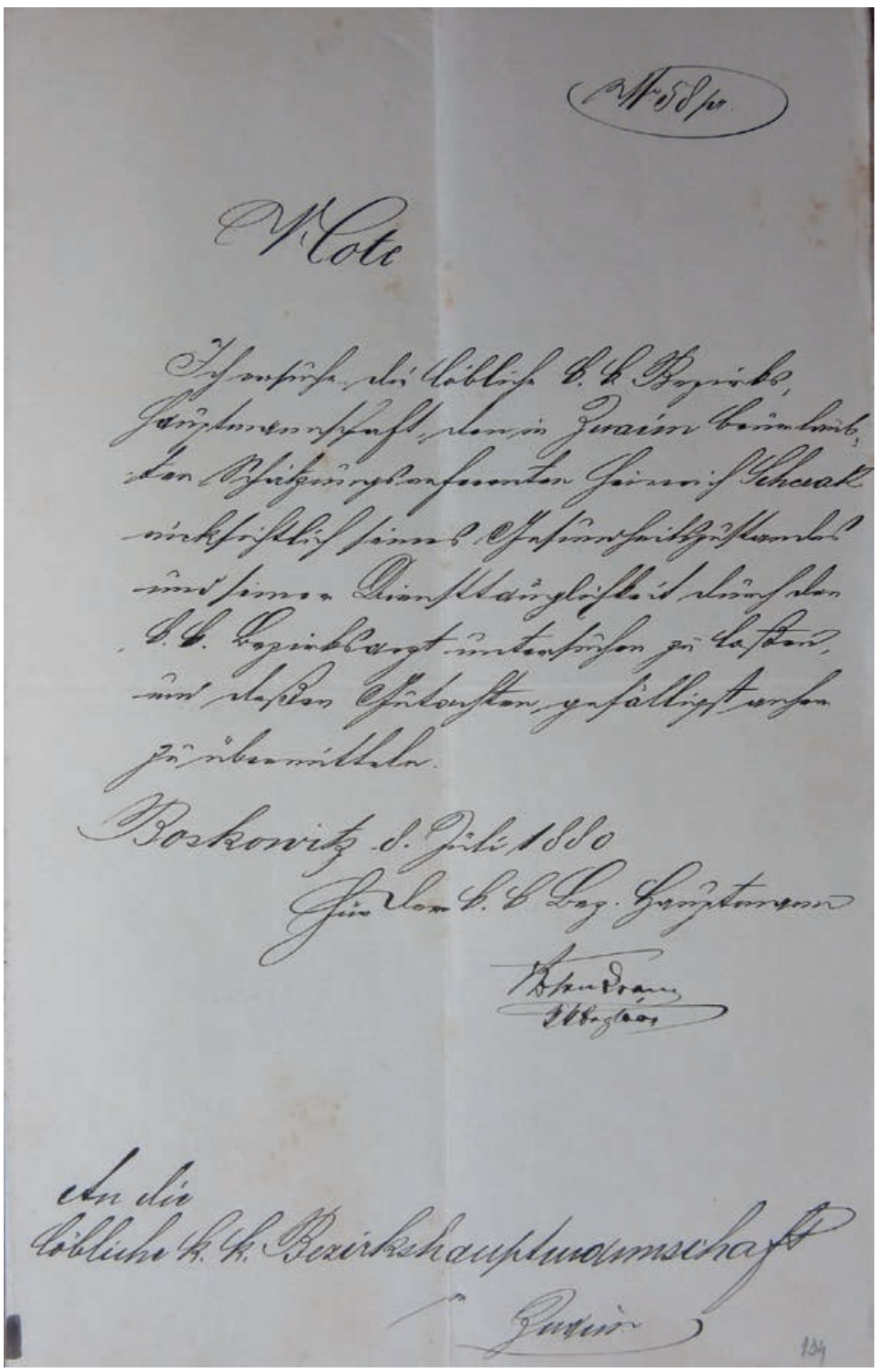

Obr. 2: Nóta Okresnímu hejtmanství ve Znojmě (SOkA Blansko, fond Okresní úrad Boskovice 1850-1945, kart. 1, fol. 134r) 


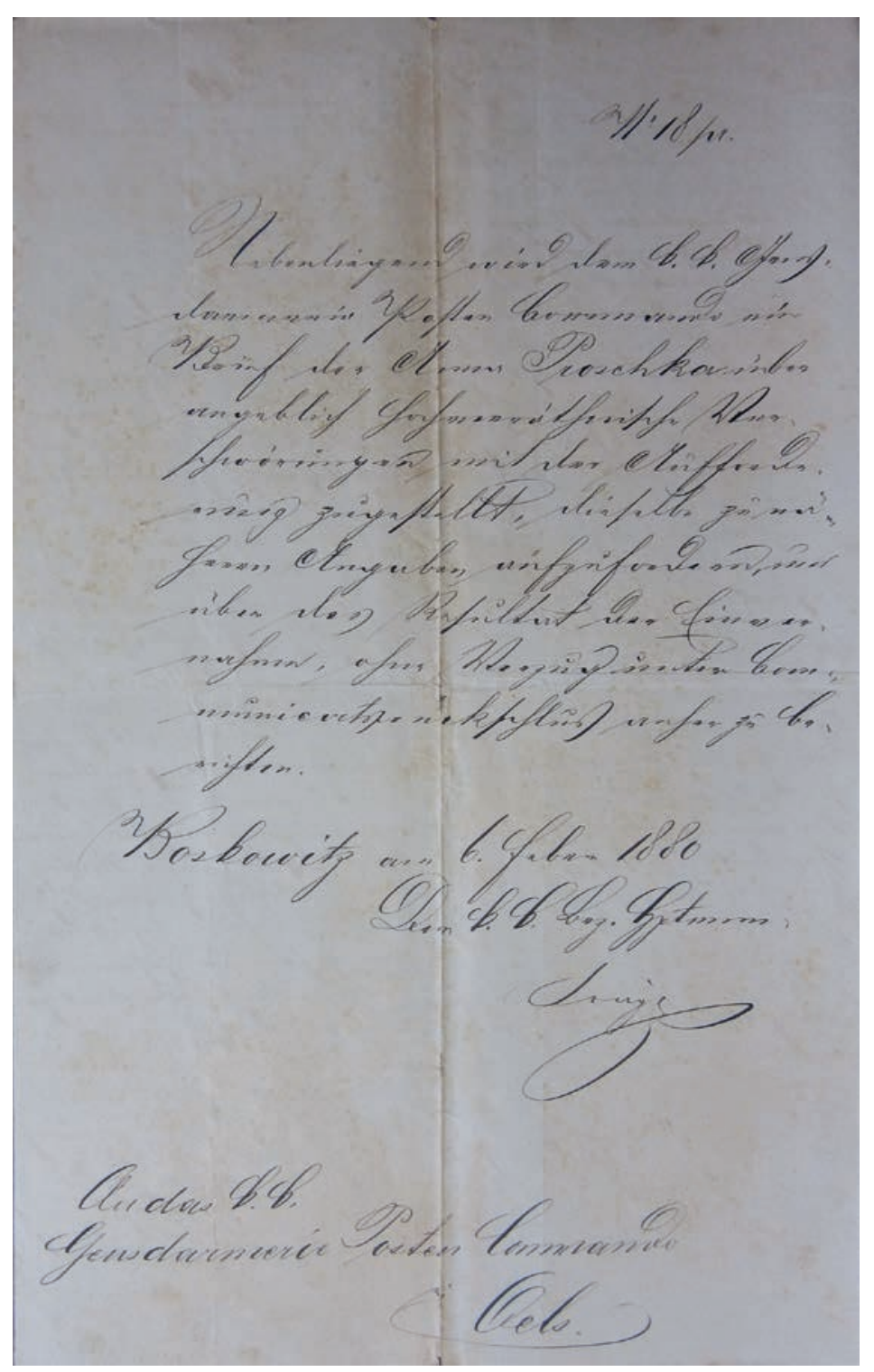

Obr. 3: Výnos Četnické stanici v Olešnici (SOkA Blansko, fond Okresní úřad Boskovice 1850-1945, kart. 1, fol. 87v) 


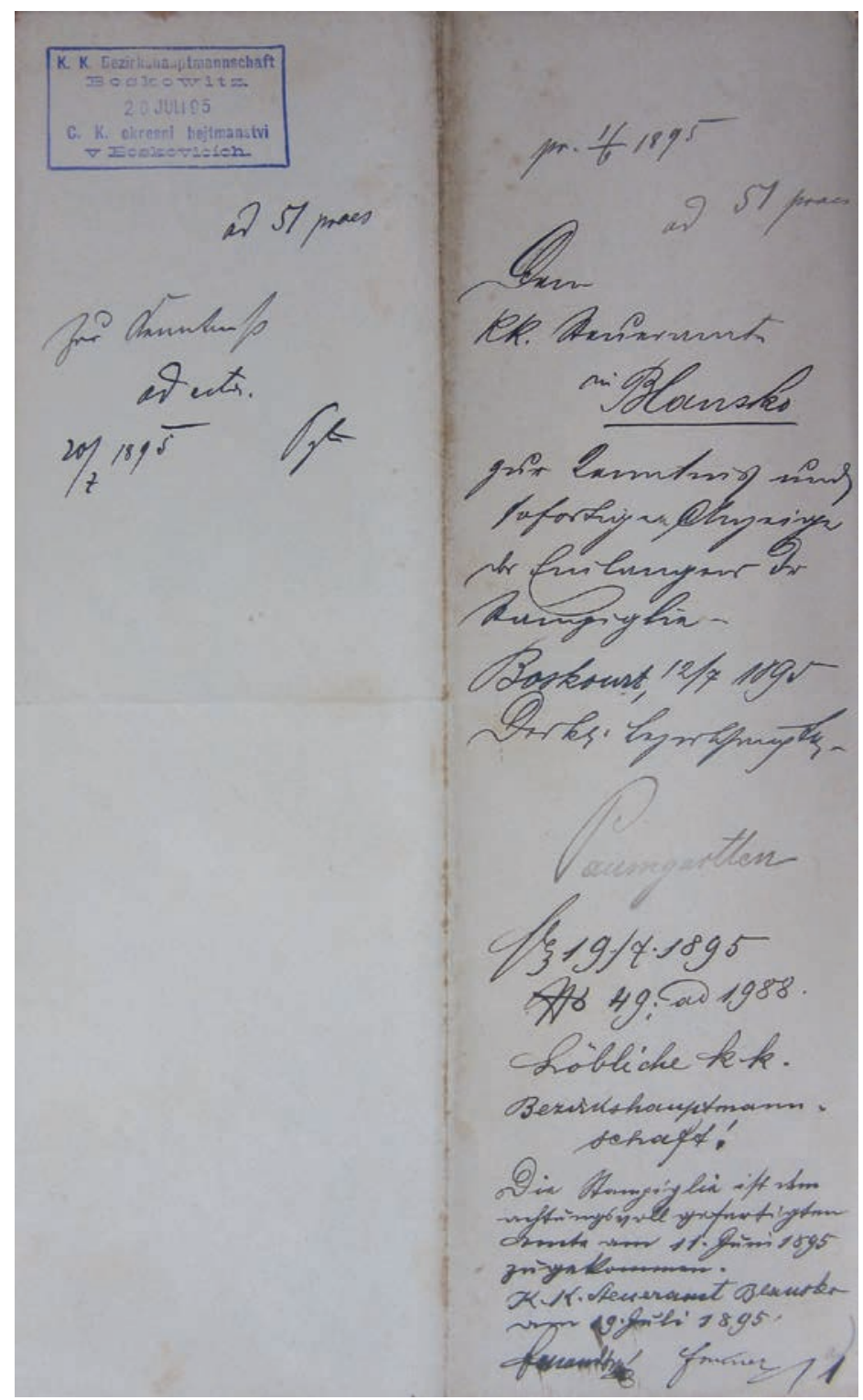

Obr. 4: Dekretace Bernímu úřadu v Blansku s podpisovým razítkem okresního hejtmana (SOkA Blansko, fond Okresní úřad Boskovice 1850-1945, kart. 6, fol. 741v) 


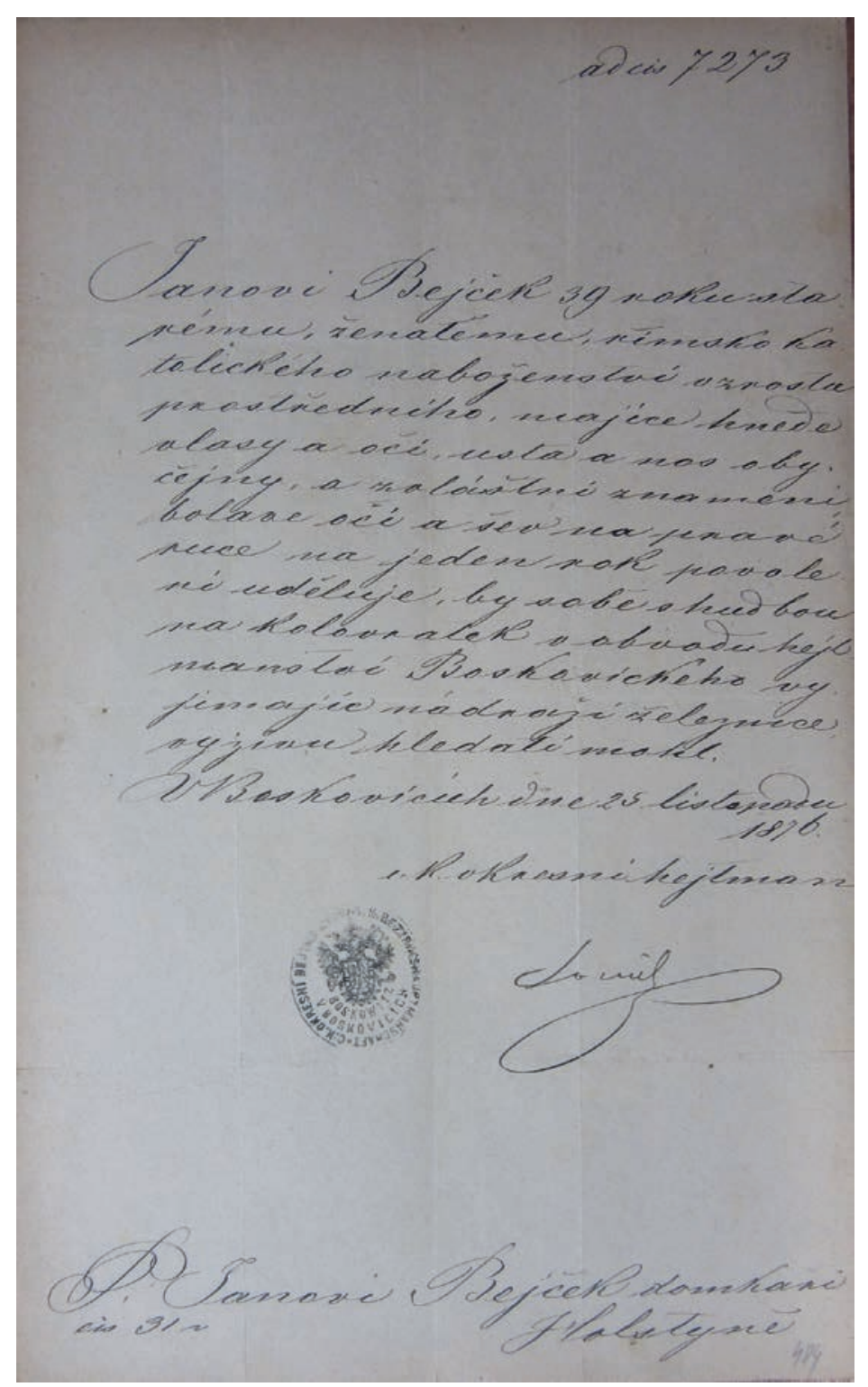

Obr. 5: Výnos opatřený otiskem úředního razítka určený soukromé osobě (SOkA Blansko, fond Okresní úřad Boskovice 1850-1945, kart. 126, fol. 484r) 
Okreanl spréva pol1tioizé

$\checkmark$ Boskovioloh. $--0-$
V Boskovioion, one $34 . z \leq r 1192 ?$.

¿is. 36899.

\section{Skody apusobené żivelnimi kata-}

strofami prumyslovism a obohodnim

podnikum

Z čs. 10404/ad/pres. ge dne 10. zär 1927.

\section{Predsedn1otvr \\ zemské správy politiaké}

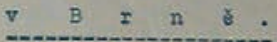

Ve zdejếm pol1tiokém okresu utrperly následujacl podniky äivelnim1 pohromami :

1. Velkostatek $\vee$ Rajo1, jemuz̃ zpứsobena úkoda na budo-

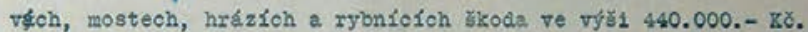

3./ Ta. B. F. Julinek $v$ Jedovnioroh $j\{\check{z}$ zpuisobena ủkoda na budovách, na zar̆fzenf pily a mlýna, dále na materílí a teraskich ve výs̆i $190.000 \mathrm{Kč}$.

3./ Leodegara Daněk, m.ynař a hostinský v Olomuðanech, utrpěvŏ́ ăkodu na zásobách, mosteoh, hrázioh, zásobíah mouky, dîlv1

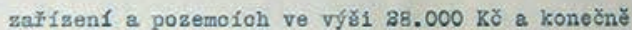

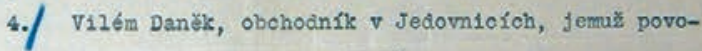
An

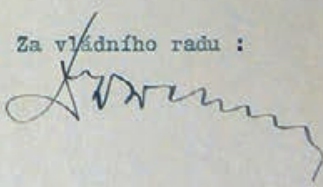

Obr. 6: Modernizovaná podoba zprávy z 20. let (SOkA Blansko, fond Okresní úřad Boskovice 1850-1945, kart. 100, fol. 298r) 


\section{Communication Papers of District Council Boskovice and Their Transformations at the Turn of the $19^{\text {th }}$ and $20^{\text {th }}$ Century}

District Council Boskovice issued three main types of communication papers between 1870 and 1928, namely reports (Berichte), notes (Noten), which were about the end of the $19^{\text {th }}$ century replaced with request letters (Zuschriften), and ordinances (Erlässe). These papers may be reckoned as successors of those ones used by authorities of administration before 1850. The type of a used paper depended on the rank of addressee. Naturally, most issued papers were intended for the inferior addressees. Besides the ordinances, circulars (Runderlässe) and "currendas" (Kurrenden) belong to this group of communication papers.

As simplified counterparts of reports, notes, or request letters, and ordinances, special papers written usually on the reverse side of a received document were made out. We call them therefore indorsements. Finally, the chief of the district council could use official letters and private official letters in case of correspondence with other chiefs, officers, and private persons.

At the turn of the $19^{\text {th }}$ and $20^{\text {th }}$ century official papers were simplified and considerably unified, for they were freed of all needless courtesies and redundant formalities. Thus, they gained the form which was typical of them at least up to 1945 . 
